\title{
PKA-Dependent Phosphorylation of Ribosomal Protein S6 Does Not Correlate with Translation Efficiency in Striatonigral and Striatopallidal Medium-Sized Spiny Neurons
}

\author{
Anne Biever, ${ }^{1,2,3 *}$ Emma Puighermanal, ${ }^{1,2,3 *}$ Akinori Nishi, ${ }^{4}$ Alexandre David, ${ }^{1,2,3}$ Claire Panciatici, ${ }^{1,2,3}$ \\ Sophie Longueville, ${ }^{5,6}$ Dimitris Xirodimas, ${ }^{7}$ Giuseppe Gangarossa,,${ }^{1,2,3}$ Oded Meyuhas, ${ }^{8}$ Denis Hervé,, 5 \\ Jean-Antoine Girault, ${ }^{5,6}$ and Emmanuel Valjent ${ }^{1,2,3}$ \\ ${ }^{1}$ Centre National de la Recherche Scientifique, Unité Mixte de Recherche 5203, Institut de Génomique Fonctionnelle, Montpellier, F-34094, France, \\ ${ }^{2}$ INSERM, U1191, Montpellier, F-34094, France; ${ }^{3}$ Université de Montpellier, Montpellier, F-34094, France, ${ }^{4}$ Department of Pharmacology, Kurume \\ University School of Medicine, Kurume, Fukuoka 830-0011, Japan, ${ }^{5}$ Université Pierre et Marie Curie, INSERM UMR-S839, Paris, F-75005 France, ${ }^{6}$ Institut \\ du Fer à Moulin, F-75005, Paris, France, ${ }^{7}$ Centre de Recherche en Biochimie Macromoléculaire, Centre National de la Recherche Scientifique, Unité Mixte \\ de Recherche 5237, Montpellier, F-34000, France, and ${ }^{8}$ Department of Biochemistry and Molecular Biology, The Institute for Medical Research \\ Israel-Canada, The Hebrew University-Hadassah Medical School, Jerusalem 91120, Israel
}

Ribosomal protein S6 (rpS6), a component of the 40S ribosomal subunit, is phosphorylated on several residues in response to numerous stimuli. Although commonly used as a marker for neuronal activity, its upstream mechanisms of regulation are poorly studied and its role in protein synthesis remains largely debated. Here, we demonstrate that the psychostimulant D-amphetamine (D-amph) markedly increases rpS6 phosphorylation at Ser235/236 sites in both crude and synaptoneurosomal preparations of the mouse striatum. This effect occurs selectively in D1R-expressing medium-sized spiny neurons (MSNs) and requires the cAMP/PKA/DARPP-32/PP-1 cascade, whereas it is independent of mTORC1/p70S6K, PKC, and ERK signaling. By developing a novel assay to label nascent peptidic chains, we show that the rpS6 phosphorylation induced in striatonigral MSNs by D-amph, as well as in striatopallidal MSNs by the antipsychotic haloperidol or in both subtypes by papaverine, is not correlated with the translation of global or $5^{\prime}$ terminal oligopyrimidine tract mRNAs. Together, these results provide novel mechanistic insights into the in vivo regulation of the post-translational modification of rpS6 in the striatum and point out the lack of a relationship between PKA-dependent rpS6 phosphorylation and translation efficiency.

Key words: D-amphetamine; dopamine; protein synthesis; ribosomal protein S6; striatum

\section{Introduction}

Through integration of glutamate and dopamine neurotransmission, the principal neurons of the striatum, the GABAergic medium-

Received Aug. 8, 2014; revised Dec. 16, 2014; accepted Jan. 13, 2015.

Author contributions: A.B., E.P., and E.V. designed research; A.B., E.P., A.N., C.P., S.L., G.G., and D.H. performed research; A.D., D.X., O.M., D.H., J.-A.G., and E.V. contributed unpublished reagents/analytic tools; A.B., E.P., A.N., C.P., and E.V. analyzed data; A.B., E.P., J.-A.G., and E.V. wrote the paper.

This work was supported by Inserm, ATIP-Avenir (Inserm), Sanofi-Aventis R\&D, Agence Nationale de la Recherche (Grant ANR-2010-JCJC-1412 to E.V.). Research in JAG and DH laboratories was supported by grants from the Fondation pour la Recherche Médicale (FRM), the Agence Nationale de la Recherche (Grant ANRBLAN08-1_346422), European Union Framework program 7 (FP7, SynSys), and the European Research Council (ERC). A.B. is supported by the Fonds National de la Recherche, Luxembourg (Grant 3977033). E.P. was a recipient of an EMBO Fellowship with the support of European Commission (Grants EMBOCOFUND2010 and GA-2010-267146) and a Marie Curie Intra-European Fellowship IEF327648. We thank Mario Pende (Inserm U845) for providing the $\mathrm{p} 7056 \mathrm{~K} 1 / 2$ double knock-out mice and for discussion on the early version of this manuscript.

The authors declare no competing financial interests.

Correspondence should be addressed to Emmanuel Valjent, Inserm U1191, CNRS UMR 5203, Institut de Génomique Fonctionnelle, 141 rue de la Cardonille, 34094 Montpellier Cedex 05, France. E-mail: emmanuel.valjent@igf.cnrs.fr or emmanuel.valjent@gmail.com.

C. Panciatici's present address: FRE3377, Gif-sur-Yvette, F-91190, France.

*A.B. and E.P. contributed equally to this work. sized spiny neurons (MSNs), process dopamine-mediated reward signals to generate appropriate behavior in responses to given glutamate-mediated cortical and thalamic inputs (Wickens et al., 2003). In MSNs, the cellular actions of dopamine (DA) are mediated mainly by G-protein-coupled dopamine D1 and D2 receptors (D1R, D2R). Whereas D1Rs stimulate cAMP production and are preferentially localized in MSNs projecting to the substantia nigra pars reticulata and the entopeduncular nucleus, D2Rs inhibit cAMP production and are expressed by MSNs projecting to the lateral part of the globus pallidus.

The generation of various BAC transgenic mouse lines largely contributed to demonstrating the opposite regulation of phosphorylation events [dopamine- and cAMP-regulated phosphoprotein, $M_{\mathrm{r}}$ 32,000 (DARPP-32) and the extracellular signal-regulated kinase (ERK) pathway] and immediate early genes expression (c-Fos, Zif268, $\Delta$ FosB) in striatonigral and striatopallidal MSNs in response to various stimuli (Bateup et al., 2008; Bertran-Gonzalez 
et al., 2008; Valjent et al., 2009; Lobo et al., 2013). Although psychostimulant drugs exert potent cellular and molecular effects mostly in D1R-expressing MSNs (Lobo and Nestler, 2011), antipsychotic drugs affect preferentially D2R-containing MSNs (Bertran-Gonzalez et al., 2010). However, the existence of such a dichotomy on the signaling events that regulate the translation machinery in the striatum remains largely unexplored.

Ribosomal protein S6 (rpS6) is a component of the small $40 \mathrm{~S}$ ribosomal subunit that undergoes phosphorylation on five evolutionarily conserved residues (Ser235, Ser236, Ser240, Ser244, and Ser247) in response to a wide variety of stimuli (Meyuhas, 2008). rpS6 phosphorylation is tightly controlled by the canonical pathway mammalian target of rapamycin complex 1 (mTORC1)/p70 ribosomal protein S6 kinases 1 and 2 (p70S6K1/2) (Meyuhas, 2008), as well as by ERK (Sturgill et al., 1988; Roux et al., 2007), casein kinase 1 (Hutchinson et al., 2011), PKC (House et al., 1987; Yano et al., 2014), and cAMP-dependent protein kinase (PKA) (Moore et al., 2009; Valjent et al., 2011; Yano et al., 2014) signaling cascades. Despite the common use of rpS6 phosphorylation as a marker for neuronal activity in brain studies (Knight et al., 2012), its regulation is still poorly studied and its involvement in the translation of global or a specific subset of mRNAs bearing a $5^{\prime}$ terminal oligopyrimidine tract (TOP) remains largely debated (Meyuhas, 2008; Sengupta et al., 2010).

Here, we demonstrate that single and repeated exposure to D-amphetamine (D-amph), which increases extracellular DA levels, markedly enhances rpS6 phosphorylation at the S235/236 sites selectively in D1R-containing MSNs. This effect requires D1R/G $\alpha$ olf/PKA-mediated activation of DARPP-32/protein phosphatase-1 (PP-1) signaling, but is independent of the mTORC1/p70S6K1/2, ERK, and PKC pathways. Moreover, we show clearly that increased PKA-dependent rpS6 phosphorylation in striatonigral and striatopallidal MSNs is not correlated with changes in global protein synthesis or selective TOP mRNA translation.

\section{Materials and Methods}

\section{Animals}

Eight-week-old male C57BL/6 were purchased from Charles River Laboratories. Male and female Drd2-EGFP and Drd1a-EGFP heterozygous mice (C57BL/6), p70S6K1/2 double knock-out mice (C57BL/6129Ola), Gnal ${ }^{+/-}$(Goolf) heterozygous (C57BL/6), and DARPP-32 T34A knock-in (C57BL/6/Sv129) were generated as described previously (Belluscio et al., 1998; Gong et al., 2003; Svenningsson et al., 2003; Pende et al., 2004). Each transgenic mouse was compared with wild-type littermates of the same genetic background. Animals were housed under standardized conditions with a $12 \mathrm{~h}$ light/dark cycle, stable temperature $\left(22 \pm 1{ }^{\circ} \mathrm{C}\right)$, controlled humidity $(55 \pm 10 \%)$, and food and water ad libitum. All experiments were in accordance with the guidelines of the French Agriculture and Forestry Ministry for handling animals (D34-172-13).

\section{Drugs and treatments}

(5R,10S)-(+)-5-Methyl-10,11-dihydro-5H-dibenzo[a,d]cyclohepten5,10-imine hydrogen maleate ((+)-MK801, $0.1 \mathrm{mg} / \mathrm{kg})$, Ro 25-6981 (10 $\mathrm{mg} / \mathrm{kg}), \mathrm{SCH} 23390(0.15 \mathrm{mg} / \mathrm{kg})$, 6-methyl-2-(phenylethynyl)pyridine (MPEP, $15 \mathrm{mg} / \mathrm{kg}$ ), and haloperidol $(0.5 \mathrm{mg} / \mathrm{kg})$ were purchased from Tocris Bioscience, and papaverine $(30 \mathrm{mg} / \mathrm{kg}),(+)-\alpha$-Methylphenethylamine [D-amph] sulfate salt $(10 \mathrm{mg} / \mathrm{kg})$, SL327 $(50 \mathrm{mg} / \mathrm{kg})$, and NPC 15437 (8 mg/kg) from Sigma-Aldrich, YM298198 hydrochloride $(15 \mathrm{mg} / \mathrm{kg})$ from Ascent Scientific, rapamycin $(10 \mathrm{mg} / \mathrm{kg})$ from LC Laboratories, and harringtonin $(10 \mu \mathrm{g})$ from Santa Cruz Biotechnology. All of the compounds used in this study were dissolved in $0.9 \%(\mathrm{w} / \mathrm{v}) \mathrm{NaCl}$ (saline) except SL327, which was suspended by sonication in a solution of
$8 \%$ Tween 80 in saline, haloperidol that was dissolved in $0.2 \%$ of acetic acid in saline, harringtonin that was dissolved in $50 \%$ ethanol, and rapamycin that was dissolved in 5\% DMSO, 5\% Tween 20, 15\% PEG 400, and $75 \%$ water. All drugs were injected intraperitoneally except harringtonin that was locally injected in the striatum (see "Stereotaxic injection of harringtonin into the striatum"). All the drugs were administered in a volume of $10 \mathrm{ml} / \mathrm{kg}$ except rapamycin, which was injected at $5 \mathrm{ml} / \mathrm{kg}$. Mice were habituated to handling and saline injection for 3 consecutive days before the day of the experiment.

\section{Stereotaxic injection of harringtonin into the striatum}

Mice were anesthetized with a mixture of ketamine (Imalgene 500, 50 $\mathrm{mg} / \mathrm{ml}$; Merial), saline and xylazine (Rompun $2 \%, 20 \mathrm{mg} / \mathrm{ml}$; Bayer) $(2: 2: 1,0.1 \mathrm{ml} / 30$ g, i.p. $)$ and mounted on a stereotaxic apparatus with a flat skull (Franklin and Paxinos, 2008). Microinjection needles were connected to two $10 \mu \mathrm{l}$ Hamilton syringes and placed into the left/right striatum $(\mathrm{A} / \mathrm{P}=0.5 \mathrm{~mm}$; Lat. $= \pm 2 \mathrm{~mm} ; \mathrm{D} / \mathrm{V}=-3.6 \mathrm{~mm})$. Two microliters of harringtonin $(5 \mathrm{mg} / \mathrm{ml}$ dissolved in $50 \%$ ethanol) were injected over $5 \mathrm{~min}$ in one hemisphere and the vehicle solution in the other hemisphere (the sides were counterbalanced). The injector was left in place for an additional $5 \mathrm{~min}$ to allow for diffusion away from injection site. Mice were killed at $60 \mathrm{~min}$ after injection and the striata of both hemispheres were extracted and processed as described in the section "Puromycin incorporation in whole striatal lysates."

\section{Western blot analysis}

After pharmacological manipulation, the heads of the mice were immediately immersed in liquid nitrogen for $4 \mathrm{~s}$. The brains were removed and the striata were rapidly dissected on an ice-cooled disk, sonicated in 300 $\mu \mathrm{l}$ of $10 \% \mathrm{SDS}$, and boiled at $100^{\circ} \mathrm{C}$ for 10 minutes. In each experiment, samples from all animal groups were processed in parallel to minimize interassay variations. Protein contents in each sample were determined by BCA protein assay (Pierce) following the manufacturer's instructions and equal amounts of brain lysates were mixed with denaturing $4 \times$ Laemmli loading buffer. Samples with equal amounts of total protein (15 $\mu$ g per lane) were separated in $13 \%$ or $7 \%$ SDS-polyacrylamide gel before electrophoretic transfer onto Immobilon-P membranes (Millipore). Membranes were cut horizontally, producing strips at different molecular weights to be probed with different primary antibodies. Membranes were blocked for $30 \mathrm{~min}$ with $4 \%$ bovine serum albumin (BSA) in $0.1 \mathrm{M}$ PBS. Afterward, membranes were incubated for $2 \mathrm{~h}$ with the primary antibodies (Table 1). Bound primary antibodies were detected with horseradish peroxidase-conjugated antibodies to rabbit or mouse (1:10,000; Cell Signaling Technology) and visualized by enhanced chemiluminescence detection (Luminata Forte Western HRP Substrate; Millipore). The optical density of the relevant immunoreactive bands was quantified after acquisition on a ChemiDoc XRS System (Bio-Rad) controlled by Image Lab software version 3.0 (Bio-Rad). Representative cropped immunoblots for display were processed with Adobe Illustrator CS4. For quantitative purposes, the optical density values of active phosphospecific antibodies were normalized to the detection of nonphosphospecific antibodies or to $\beta$-actin values in the same sample and expressed as a percentage of control treatment.

\section{Tissue preparation and immunofluorescence}

Mice were rapidly anesthetized with pentobarbital $(500 \mathrm{mg} / \mathrm{kg}$, i.p.; Sanofi-Aventis) and transcardially perfused with $4 \%$ (weight/vol) paraformaldehyde (PFA) in $0.1 \mathrm{~m} \mathrm{PBS,} \mathrm{pH} \mathrm{7.5.} \mathrm{Brains} \mathrm{were} \mathrm{postfixed} \mathrm{over-}$ night in the same solution and stored at $4^{\circ} \mathrm{C}$. Thirty-micrometer-thick sections were cut with a vibratome (Leica) and stored at $-20^{\circ} \mathrm{C}$ in a solution containing $30 \%(\mathrm{v} / \mathrm{v})$ ethylene glycol, $30 \%(\mathrm{v} / \mathrm{v})$ glycerol, and $0.1 \mathrm{~m}$ sodium phosphate buffer until being processed for immunofluorescence. Sections were processed as follows. Day 1: free-floating sections were rinsed in Tris-buffered saline (TBS; $0.25 \mathrm{~m}$ Tris and $0.5 \mathrm{M} \mathrm{NaCl}, \mathrm{pH}$ 7.5). Only for the MOR antibody staining were sections incubated for 15 $\min$ at $75^{\circ} \mathrm{C}$ in $10 \mathrm{~mm}$ citrate $/ 0.05 \%$ Tween buffer, cooled down for $\sim 30$ $\mathrm{min}$, and then rinsed 3 times in TBS. For all antibodies, after $15 \mathrm{~min}$ incubation in $0.2 \%$ Triton X-100 in TBS, sections were rinsed 3 times in TBS and blocked in 3\% BSA in TBS for $1 \mathrm{~h}$. Slices were then incubated in $1 \%$ BSA, $0.15 \%$ Triton X-100 in TBS for $72 \mathrm{~h}$ at $4^{\circ} \mathrm{C}$ with different 
Table 1. List of primary antibodies



WB, Western blot; IF, immunofluorescence.

primary antibodies (Table 1). For detection of phosphorylated proteins, $0.1 \mathrm{~mm}$ sodium fluoride was included in all buffers and incubation solutions. Day 2: sections were rinsed 3 times for $10 \mathrm{~min}$ in TBS and incubated for $45 \mathrm{~min}$ with goat Cy3-coupled anti-rabbit (1:500; Jackson ImmunoResearch Laboratories) and goat Alexa Fluor 488-coupled antimouse (1:500; Invitrogen) secondary antibodies, except for the double staining pS235/236-rpS6/ChAT, where donkey Cy3-coupled anti-goat (1:1000; Jackson ImmunoResearch Laboratories) and donkey Alexa Fluor 488-coupled anti-rabbit (1:500; Jackson ImmunoResearch Laboratories) were used. Sections were rinsed for $10 \mathrm{~min}$ twice in TBS and twice in $0.25 \mathrm{M}$ Tris buffer before mounting in 1,4-Diazabicyclo-[2. 2. 2]-octane (DABCO; Sigma).

Confocal microscopy and image analysis were performed at the Montpellier RIO Imaging Facility. Images covering the entire striatum were single confocal sections acquired using sequential laser scanning confocal microscopy (LSM780; Zeiss) and stitched together as a single image. Double-labeled images from each region of interest were either single or stack confocal sections obtained using sequential laser scanning confocal microscopy (LSM780; Zeiss). Photomicrographs were obtained with the following bandpass and long-pass filter setting: Alexa Fluor 488/Cy2 (bandpass filter: 505-530), Сy3 (bandpass filter: 560-615), and Cy5 (long-pass filter 650). All parameters were held constant for all sections from the same experiment.

\section{Synaptoneurosomal preparation}

After pharmacological manipulation, the heads of the mice were immediately immersed in liquid nitrogen for $4 \mathrm{~s}$. The brains were removed and the striata were rapidly dissected on an ice-cooled dish and homogenized using 20 up-and-down strokes of a prechilled glass homogenizer with 1 $\mathrm{ml}$ of synaptoneurosome buffer containing the following (in $\mathrm{mM}$ ): 2.5 $\mathrm{CaCl}_{2}, 124 \mathrm{NaCl}, 3.2 \mathrm{KCl}, 1.06 \mathrm{KH}_{2} \mathrm{PO}_{4}, 26 \mathrm{NaHCO}_{3}, 1.3 \mathrm{MgCl}_{2}, 100$ $\mathrm{D}-(+)$-glucose, 20 HEPES, $\mathrm{pH} 7.4$, plus the following (in $\mu \mathrm{M}): 0.15$ aprotinin, 11 leupeptine, 1.5 pepstatin, 0.6 phenylmethylsulfonyl fluoride, 1 sodium orthovanadate, 100 sodium fluoride, 5 sodium pyrophosphate, and $40 \beta$-glycerolphosphate. One-hundred microliters of total homogenate was saved as an input. Samples were loaded into a $5 \mathrm{ml}$ of Luer-lok syringe and filtered through 3 layers of a prewetted $100-\mu \mathrm{m}$ pore nylon filter held in a $25-\mathrm{mm}$-diameter swinnex filter holder. The resulting filtrate was loaded into a $5 \mathrm{ml}$ of Luer-lok syringe, filtered through a $10-\mu \mathrm{m}$-pore nylon filter, recollected in an Eppendorf tube, and centrifuged at $4000 \times \mathrm{g}$ for $1 \mathrm{~min}$ at $4^{\circ} \mathrm{C}$. The supernatant was centrifuged at $14,000 \times g$ for $4 \mathrm{~min}$ at $4^{\circ} \mathrm{C}$. Pellets containing synaptoneurosome preparation were suspended again in $100 \mu$ l of synaptoneurosome buffer and boiled at $100^{\circ} \mathrm{C}$ for $10 \mathrm{~min}$. Protein concentrations were determined using BCA protein assay (Pierce) and samples were stored at $-20^{\circ} \mathrm{C}$ for further Western blot analyses.

Preparation, incubation, and immunoblotting of neostriatal slices Male C57BL/6 mice at 6-8 weeks of age were purchased from Japan SLC. Mice were killed by decapitation and the brains were rapidly removed and placed in ice-cold, oxygenated Krebs- $\mathrm{HCO}_{3}^{-}$buffer containing the following (in mM): $124 \mathrm{NaCl}, 4 \mathrm{KCl}, 26 \mathrm{NaHCO}_{3}, 1.5 \mathrm{CaCl}_{2}, 1.25$ $\mathrm{KH}_{2} \mathrm{PO}_{4}, 1.5 \mathrm{MgSO}_{4}$, and 10 D-glucose, $\mathrm{pH}$ 7.4. Coronal slices $(350 \mu \mathrm{m})$ were prepared using a vibrating blade microtome (VT1000S; Leica Mi- 
crosystems), as described previously (Nishi et al., 2005). Striata were dissected from the slices in ice-cold $\mathrm{Krebs}-\mathrm{HCO}_{3}^{-}$buffer. Each slice was placed in a polypropylene incubation tube with $2 \mathrm{ml}$ of fresh Krebs$\mathrm{HCO}_{3}^{-}$buffer. The slices were preincubated at $30^{\circ} \mathrm{C}$ under constant oxygenation with $95 \% \mathrm{O}_{2} / 5 \% \mathrm{CO}_{2}$ for $30 \mathrm{~min}$. Slices were then pretreated with an adenosine $\mathrm{A}_{2 \mathrm{~A}}$ receptor antagonist, ZM241385 $(1 \mu \mathrm{M})$, for 60 min to reduce adenosine-induced PKA activity in striatopallidal MSNs and treated with drugs as specified in each experiment. Drugs were obtained from the following sources: forskolin and Rp-cAMP from SigmaAldrich; U0126 and ZM241385 from Tocris Bioscience Cookson. After drug treatment, slices were transferred to Eppendorf tubes, frozen on dry ice, and stored at $-80^{\circ} \mathrm{C}$ until being assayed. Frozen tissue samples were sonicated in boiling $1 \%$ SDS and boiled for an additional $10 \mathrm{~min}$. Small aliquots of the homogenate were retained for protein determination by the BCA protein assay method (Pierce). Equal amounts of protein $(10-40 \mu \mathrm{g})$ were loaded onto $4-12 \%$ polyacrylamide Bis-Tris gels (\#345-0124; Bio-Rad), separated by electrophoresis, and transferred to nitrocellulose membranes $(0.2 \mu \mathrm{m})$ (Schleicher and Schuell). The membranes were immunoblotted using primary antibodies listed in Table 1. None of the experimental manipulations used in the present study altered the total levels of rpS6, DARPP-32, or ERK2 protein. The membrane was incubated with a goat anti-rabbit Alexa Fluor 680-linked IgG (1:5000; Invitrogen) or a goat anti-mouse RDye800-linked IgG (1:5000; Rockland). Fluorescence at infrared wavelengths was detected by the Odyssey infrared imaging system (LI-COR), and quantified using Odyssey software. In an individual experiment, samples from control and drug-treated slices were analyzed on the same immunoblot. For each experiment, values obtained for slices were normalized to values for the control slice. Normalized data from multiple experiments were averaged and statistical analysis was performed as described in the figure legends.

\section{Assessment of protein synthesis}

Polysome profiling. After pharmacological manipulation, the heads of the mice were immediately immersed in liquid nitrogen for $4 \mathrm{~s}$. The brains were removed and the striata of 2 mice were rapidly dissected on an ice-cooled dish, pooled, and homogenized using 30 up-and-down strokes of a prechilled glass homogenizer with $800 \mu$ l of polysomal buffer containing $20 \mathrm{~mm}$ Tris, pH 7.2, $130 \mathrm{mM} \mathrm{KCl}, 10 \mathrm{mM} \mathrm{MgCl}_{2}, 0.05 \%$ Nonidet P-40, $100 \mu \mathrm{g} / \mathrm{ml}$ cycloheximide, $2.5 \mathrm{~mm}$ DTT, and $200 \mathrm{U} / \mathrm{ml}$ Rnasin (Promega) and protease inhibitor mixture (Roche) for $15 \mathrm{~min}$ on ice. Samples were centrifuged for $5 \mathrm{~min}$ at $16,100 \times g$ at $4^{\circ} \mathrm{C}$ and supernatant containing $200 \mu \mathrm{g}$ of RNA was loaded onto $10-50 \%$ sucrose density gradients containing the following (in mM): 50 Tris, $\mathrm{pH} \mathrm{7.5,} 25$ $\mathrm{KCl}, 10 \mathrm{MgCl}_{2}$, and $1 \mathrm{DTT}$. Samples were centrifuged for $3 \mathrm{~h}$ at 36,000 r.p.m at $4^{\circ} \mathrm{C}$ in a SW41 Ti swing-out rotor. Ribosome profiling was performed using a density gradient fractionation system (Brandel) with upward displacement and continuous monitoring at $254 \mathrm{~nm}$ using a UA-6 detector.

Puromycin incorporation in whole striatal lysates. After pharmacological manipulation, the heads of the mice were immediately immersed in liquid nitrogen for $4 \mathrm{~s}$. The brains were removed and the striata were rapidly dissected on an ice-cooled dish and homogenized using 20 upand-down strokes of a prechilled glass homogenizer with $800 \mu \mathrm{l}$ of polysomal buffer containing $50 \mathrm{~mm}$ Tris, $\mathrm{pH} 7.8,240 \mathrm{~mm} \mathrm{KCl,} 10 \mathrm{~mm} \mathrm{MgCl}_{2}$, $250 \mathrm{~mm}$ D-sucrose, $2 \%$ Triton X-100, $20 \mu \mathrm{l} / \mathrm{ml}$ emetine, 5 mм DTT, 100 $\mathrm{U} / \mathrm{ml}$ Rnasin (Promega), and protease inhibitor mixture (Roche). Samples were centrifuged for $5 \mathrm{~min}$ at $16,100 \times g$ at $4^{\circ} \mathrm{C}$ and supernatant was incubated with $100 \mu \mathrm{g} / \mathrm{ml}$ puromycin for $10 \mathrm{~min}$ at $4^{\circ} \mathrm{C}$ and then boiled for $10 \mathrm{~min}$ at $100^{\circ} \mathrm{C}$. Protein concentrations were determined using $\mathrm{BCA}$ protein assay (Pierce) and samples were stored at $-20^{\circ} \mathrm{C}$ for further Western blot analyses.

Puromycin incorporation in the synaptoneurosomal fraction. For puromycin incorporation in the synaptoneurosomal fraction, the synaptoneurosome buffer supplemented with $20 \mu \mathrm{l} / \mathrm{ml}$ emetine, $5 \mathrm{~mm}$ DTT, and $100 \mathrm{U} / \mathrm{ml}$ Rnasin (Promega) was used. After following the protocol of synaptoneurosomal preparation, $100 \mu \mathrm{l}$ of resuspended pellets were incubated with $100 \mu \mathrm{g} / \mathrm{ml}$ puromycin for $10 \mathrm{~min}$ at $4^{\circ} \mathrm{C}$ and then boiled for $10 \mathrm{~min}$ at $100^{\circ} \mathrm{C}$. Protein concentrations were determined using $\mathrm{BCA}$ protein assay (Pierce) and samples were stored at $-20^{\circ} \mathrm{C}$ for further Western blot analyses.

Puromycin intracerebroventricular administration and immunofluorescence. Drd2-EGFP mice were anesthetized as previously described and mounted on a stereotaxic apparatus with a flat skull. A stainless steel 22-gauge guide cannula (PlasticsOne, Roanoke, VA) was implanted vertically towards the left lateral ventricle $(\mathrm{A} / \mathrm{P}=-0.22 \mathrm{~mm}$; Lat. $-1 \mathrm{~mm}$; $\mathrm{D} / \mathrm{V}-2 \mathrm{~mm}$ ). Guide cannulas were fixed onto the skull with instant adhesive and dental cement (Dentalon Plus; Heraeus, Hanau, Germany) bonded to stainless steel screws anchored to the skull. An obturator was inserted into each guide cannula and remained in place until the drug infusion when it was removed and replaced with an injector that extended $0.5 \mathrm{~mm}$ beyond the tip of the guide cannula. After surgery recovery, mice were treated with saline or D-amph $(10 \mathrm{mg} / \mathrm{kg})$ and, 1 or $2 \mathrm{~h}$ later, $3 \mu \mathrm{l}$ of puromycin solution $(9 \mathrm{mg} / \mathrm{ml}, 10 \% \mathrm{DMSO} / 90 \%$ saline) or vehicle were infused during $1 \mathrm{~min}$ into the cannula through polyethylene tubing using an infusion pump (Stoelting). After drug infusion, the tubing remained in place for 1 extra minute to ensure proper delivery of the solution. All mice were previously handled to warrant proper immobility during intracerebroventricular. administration. Five minutes after puromycin infusion, mice were anesthetized with pentobarbital $(500 \mathrm{mg} / \mathrm{kg}$, i.p.; Sanofi-Aventis) and transcardially perfused for $1 \mathrm{~min}$ with saline followed by 2 min of 4\% PFA in 0.1 M PBS, pH 7.5, containing $1 \mathrm{~mm}$ sodium orthovanadate and $50 \mathrm{~mm}$ sodium fluoride. Brains were postfixed $1 \mathrm{~h}$ in the same solution and stored at $4^{\circ} \mathrm{C}$ in $0.1 \mathrm{M}$ PBS. Thirtymicrometer-thick sections were cut with a vibratome (Leica) and stored at $-20^{\circ} \mathrm{C}$ in a solution containing $30 \%$ ethylene glycol, $30 \%$ glycerol, and $0.1 \mathrm{~m}$ sodium phosphate buffer. Immunofluorescence was adapted from previously described methods (David et al., 2012). Briefly, sections were incubated for $20 \mathrm{~min}$ with coextraction/fixation buffer $(50 \mathrm{~mm}$ Tris- $\mathrm{HCl}$, $\mathrm{pH} 7.5,5 \mathrm{~mm} \mathrm{MgCl}_{2}, 25 \mathrm{~mm} \mathrm{KCl}$, protease inhibitor mixture (Roche), $0.015 \%$ digitonin (Wako Chemicals), and 3\% PFA and postfixed for 15 min with 3\% PFA. After 3 rinses with $0.1 \mathrm{M}$ PBS, sections were incubated overnight at $4^{\circ} \mathrm{C}$ with $\mathrm{pS} 235 / 236$-rpS6, GFP, and puromycin antibodies in a solution containing $0.05 \%$ saponin, $10 \mathrm{~mm}$ glycine, and $5 \%$ fetal bovine serum in $0.1 \mathrm{M}$ PBS. After 3 rinses in $0.1 \mathrm{M}$ PBS, incubation with secondary antibodies, slice mounting, and confocal image acquisition were performed as described in the "Tissue preparation and immunofluorescence" section.

\section{Statistical analysis}

All statistical analyses were performed using one-way ANOVA for multiple comparisons, followed by Newman-Keuls post hoc test. Student's $t$ test with equal variances was used for groups of two when relevant. Statistical significance was determined as $p<0.05$. GraphPad Prism version 5.0 software was used to perform statistical analyses.

\section{Results}

\section{D-amph increases rpS6 phosphorylation in striatonigral MSNs through D1R stimulation}

By enhancing extracellular DA levels in the striatum, psychostimulant drugs such as D-amph exert potent effects on signaling in D1R-expressing MSNs (Lobo and Nestler, 2011). We examined the phosphorylation state of rpS6 in the mouse striatum in response to a single administration of $\mathrm{D}$-amph $(10 \mathrm{mg} / \mathrm{kg})$. The phosphorylation sites of rpS6 have been mapped to five clustered residues, S235, S236, S240, S244, and S247, located at the C terminus of the protein (Krieg et al., 1988). In whole striatal lysates, we found a rapid and sustained increase in phospho-rpS6 at S235/236 sites (pS235/236-rpS6) in mice treated with D-amph, which was maximal between 15 and 60 min (Fig. 1A). Interestingly, in mice repeatedly exposed (10 $\mathrm{mg} / \mathrm{kg}$ once daily for $4 \mathrm{~d}$ ) and then challenged on day 5 with D-amph, pS235/236-rpS6 was still strongly increased in the striatum (Fig. $1 B$ ). In contrast, a slight, statistically insignificant increase in the phosphorylation of rpS6 at S240/244 sites (pS240/244-rpS6) was observed after acute (saline, $100 \pm 13.4$; D-amph $15 \mathrm{~min}, 140 \pm 19.4$; 
A
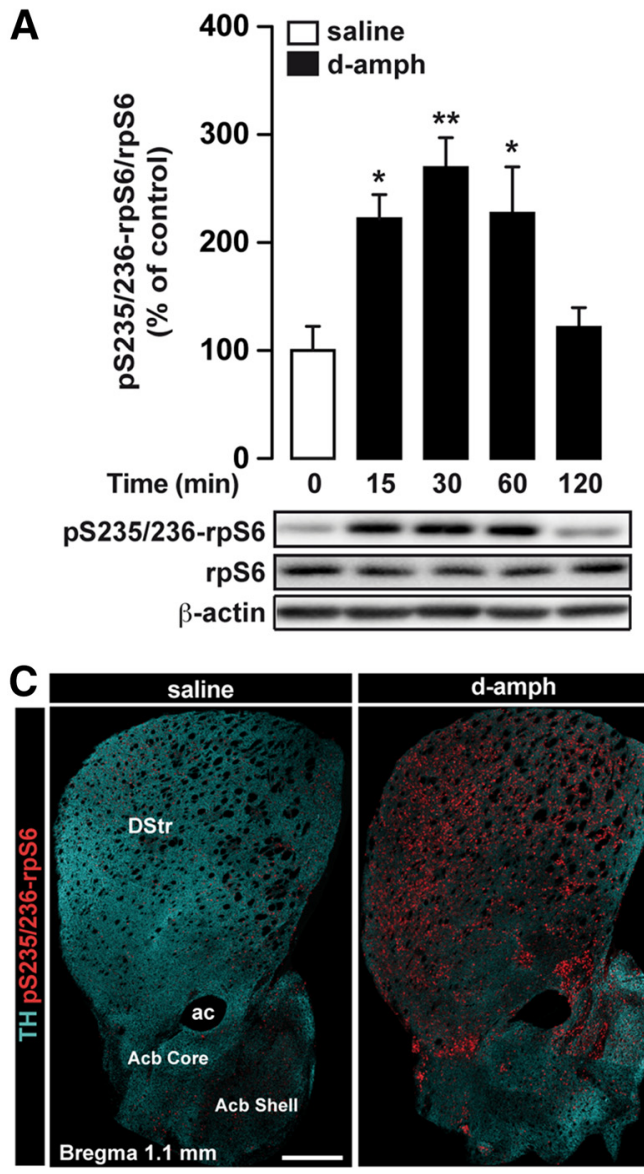

D
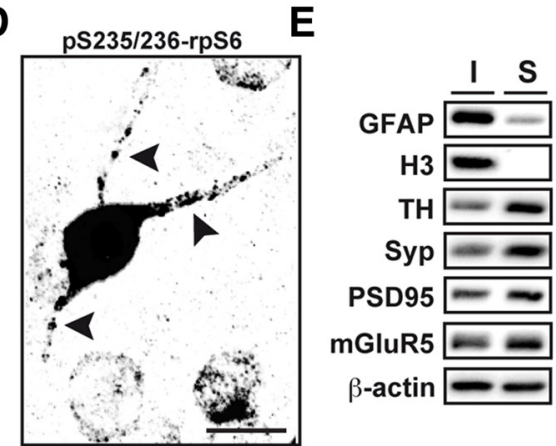

B
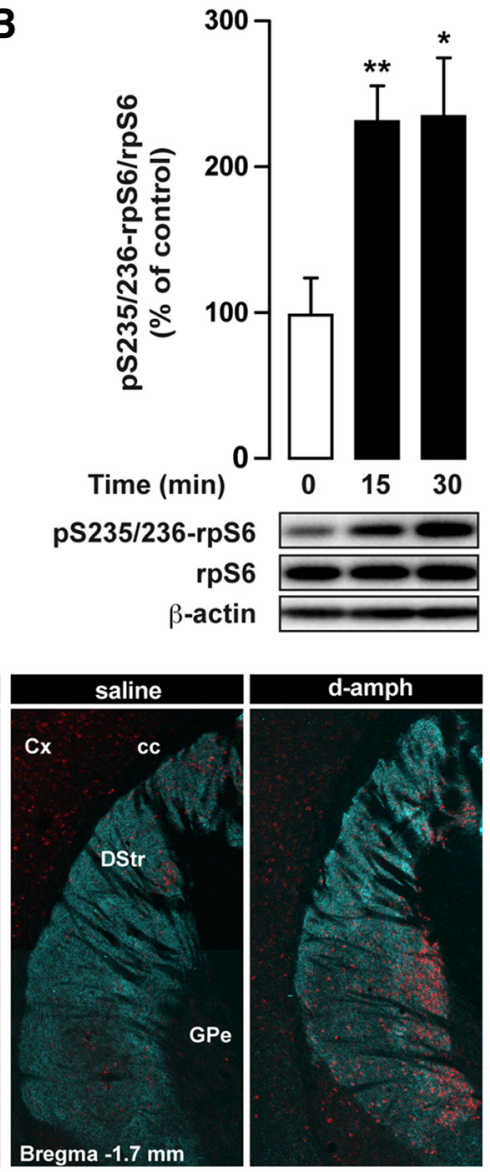

E

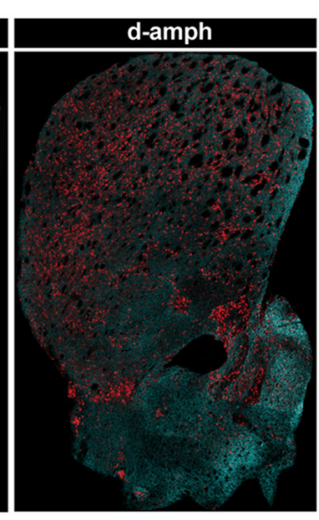

$\mathbf{F}$

Figure 1. Acute D-amph increases rpS6 phosphorylation in whole and synaptoneurosomal fractions of the striatum. $\boldsymbol{A}$, $\boldsymbol{B}$, Quantified (top) and representative (bottom) Western blot data of phosphorylated rpS6 at $\$ 235 / 236$ sites in the striatum of mice treated acutely $(\boldsymbol{A})$ or chronically (once daily for $5 \mathrm{~d})(\boldsymbol{B})$ with D-amph $(10 \mathrm{mg} / \mathrm{kg})$ and killed at different time points after injection. Data are expressed as a percentage of untreated control ( $n=6 \mathrm{mice} / \mathrm{group}$ ). Phosphorylated rpS6 levels were normalized to rpS6. Results are represented as mean \pm SEM. ${ }^{*} p<0.05,{ }^{* *} p<0.01$, by one-way ANOVA followed by Newman-Keuls test (D-amph vs saline). C, Double immunostaining for pS235/236-rpS6 (red) and TH (cyan) in coronal rostral (bregma $1.1 \mathrm{~mm}$ ) and caudal (bregma $-1.7 \mathrm{~mm}$ ) sections of the striatum from mice receiving a single injection of saline or D-amph $(10 \mathrm{mg} / \mathrm{kg})$ and perfused $15 \mathrm{~min}$ after injection. Scale bar, $400 \mu \mathrm{m}$. D, High-magnification image of pS235/236-rpS6 immunostaining in striatal coronal sections from mice treated with D-amph (10 mg/kg) and killed 15 min after injection. Black arrowheads indicate pS236/236-rpS6 in dendrites. Note that, to detect dendritic pS235/236-rpS6, the staining of the cell body was saturated. Scale bar, $10 \mu \mathrm{m}$. $\boldsymbol{E}$, Representative Western blot of the glial (GFAP), nuclear (H3), presynaptic (TH and synaptophysin, Syp), and postsynaptic markers (PSD95 and mGluR5) in input (I) and synaptoneurosome (S) fractions of the striatum. $\boldsymbol{F}$, Western blot of pS235/236-rpS6 (normalized to rpS6) of the striatal synaptoneurosome preparation from mice that received a single injection of saline or D-amph (10 mg/kg) and were killed at $15 \mathrm{~min}$ after injection. Results are represented as mean \pm SEM. ${ }^{* *} p<0.01$ by Student's $t$ test $(n=6$ mice/group). DStr, Dorsal striatum; Acb, nucleus accumbens; (x, cortex; GPe, external globus pallidus; cc: corpus callosum; ac, anterior commissure.

D-amph $30 \min , 130.4 \pm 22.1 ; \mathrm{D}$-amph $60 \mathrm{~min}, 118.7 \pm 11.3$ and $\mathrm{D}$-amph 120 min, $105.3 \pm 4.4: n=5$ mice/group, $p=$ $0.116, \mathrm{NS}$ ) and repeated (saline, $100 \pm 9.5$; D-amph 15 min, $136.6 \pm 13.2$ and D-amph 30 min, $171.4 \pm 37.6: n=6$ mice/group, $p=$ $0.136, \mathrm{NS}) \mathrm{D}$-amph administration.

Given the robustness of pS235/236-rpS6 modulation by $\mathrm{D}$-amph in the mouse striatum, we focused our study on the regulation of these residues. We first analyzed several regions of the striatum at different levels along the rostrocaudal axis by performing double-immunofluorescence staining of pS235/236-rpS6 and tyrosine hydroxylase (TH) after acute D-amph administration. D-amph-induced pS235/236-rpS6 was observed at the rostral level in the dorsal striatum and NAc (core and shell). D-amph enhanced pS235/236-rpS6 in the whole dorsolateral striatum, whereas rpS6 phosphorylation in the ventromedial striatum was preferentially increased in specific areas that might correspond to the striatal patch compartments (Fig. 1C, left). The increase in pS235/236-rpS6 induced by D-amph was also observed in the caudal part of the striatum (Fig. 1C, right).pS235/ 236-rpS6 immunoreactivity was detected in perikarya and in primary dendrites of striatal neurons (Fig. 1D). To further characterize pS235/236-rpS6 at the synaptic level, we prepared synaptoneurosomal fractions of striatal lysates from mice acutely treated with saline or D-amph. The weak staining of glial and nuclear markers, glial fibrillary acidic protein (GFAP), and histone 3 (H3), respectively, as well as the enrichment of the presynaptic markers $\mathrm{TH}$ and synaptophysin (Syp) and the postsynaptic markers postsynaptic density protein-95 (PSD95) and metabotropic glutamate receptor 5 (mGluR5), indicated the purity of the synaptoneurosome preparations (Fig. 1E). Increased immunoreactivity of pS235/236-rpS6 in the striatal synaptoneurosomal fraction strongly indicated that rpS6 phosphorylation also occurred in the dendritic compartment after D-amph administration (Fig. $1 F$ ).

Striatal output neurons segregate into patch and matrix compartments, which are defined on the basis of different input-output connections and specific neurochemical markers (Crittenden and Graybiel, 2011). The striatal patch compartment, also referred to as striosomes, is enriched in $\mu$-opioid receptor (MOR), whereas the extrastriosomal matrix compartment is composed of neurons containing the calbindin-D28k (Calb-D28k). Triple immunofluorescence analysis revealed that D-amph preferentially increased pS235/ 236-rpS6 in the striosomes of the ventromedial striatum, whereas rpS6 phosphorylation was 

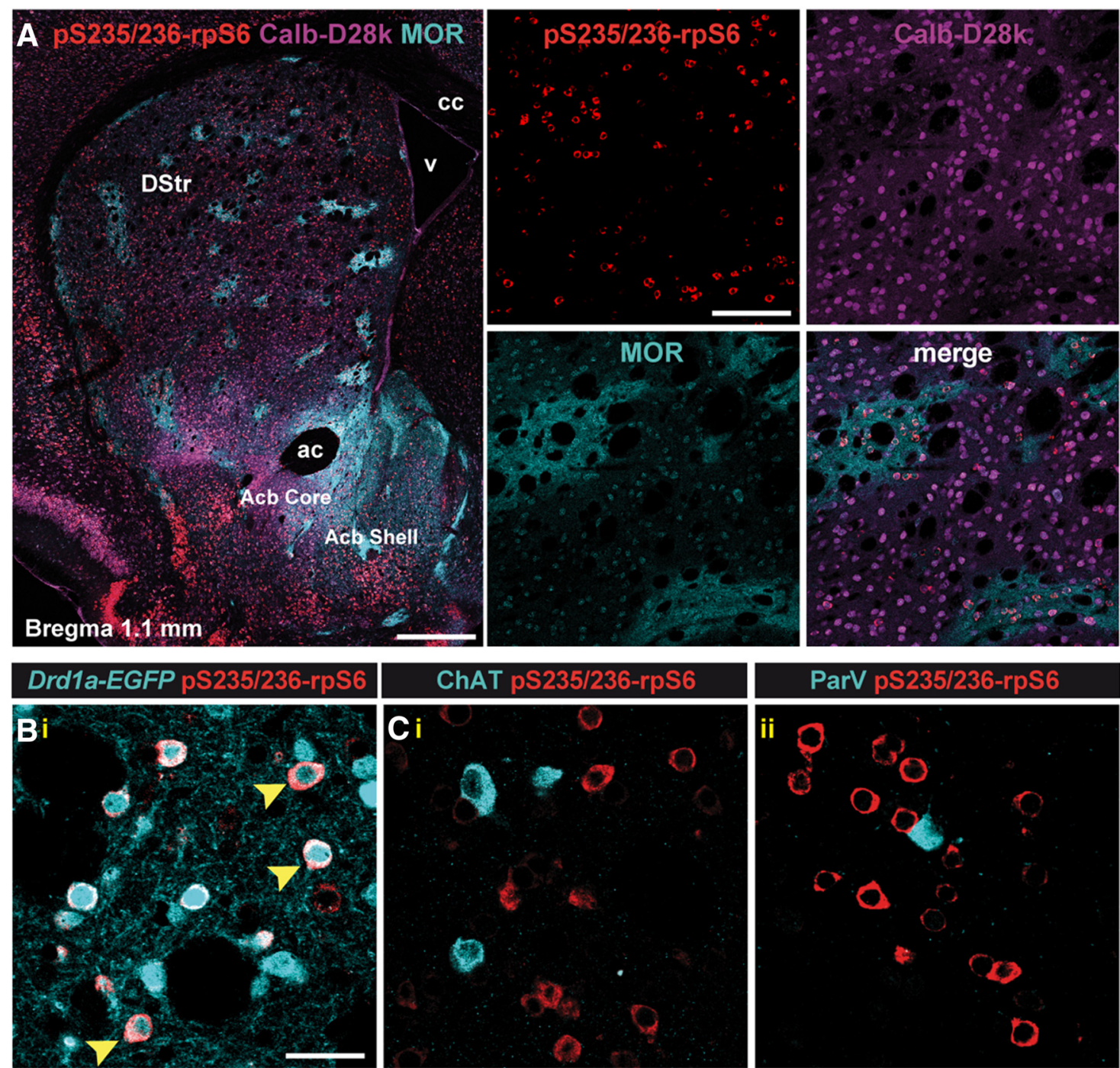

ChAT pS235/236-rpS6

ParV pS235/236-rpS6
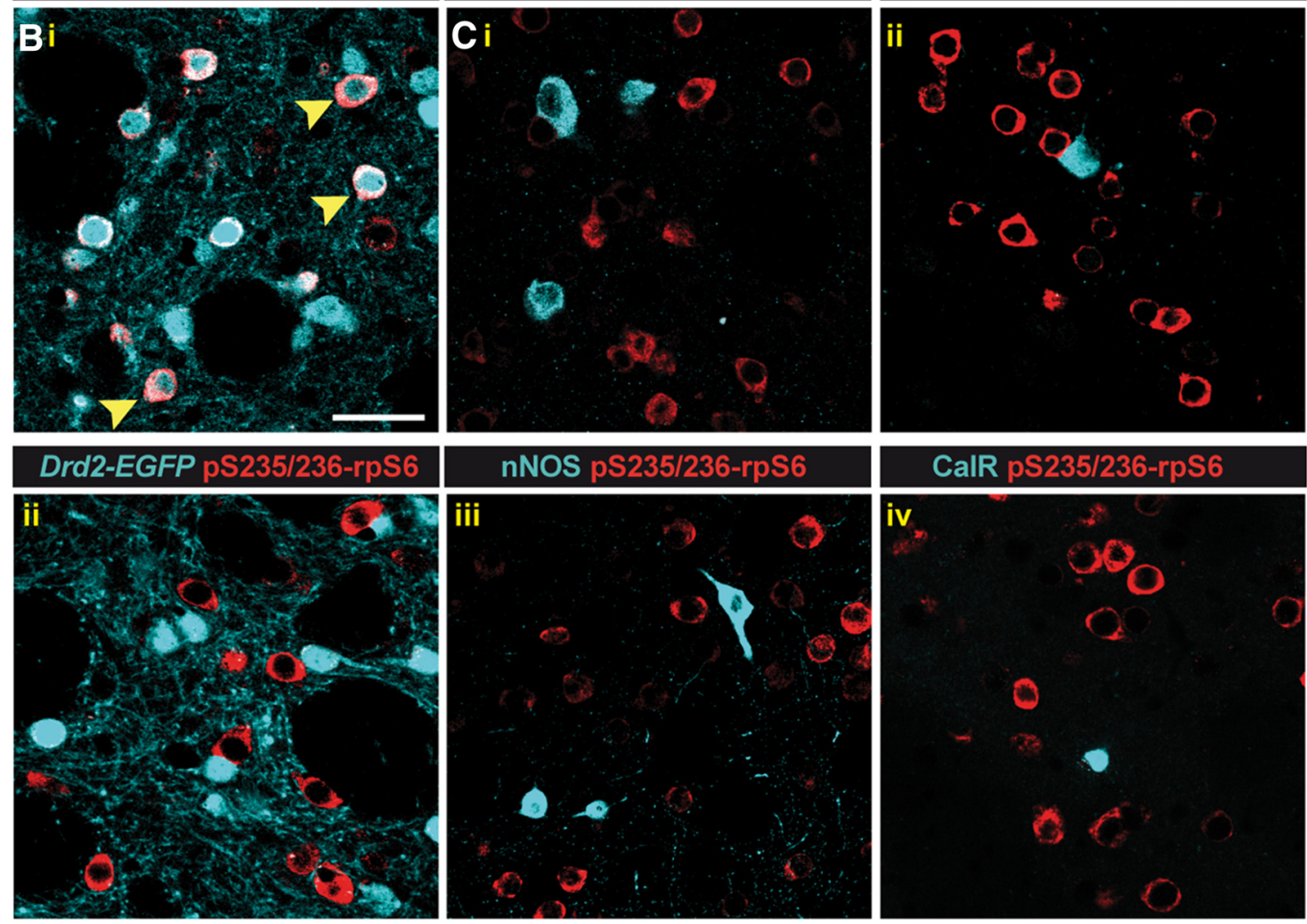

Figure 2. D-amph-induced rpS6 phosphorylation in D1R-containing MSNs. A, Triple immunostaining for pS235/236-rpS6 (red), Calb-D28k (magenta), and MOR (cyan) in coronal sections of the striatum from mice treated with D-amph (10 mg/kg) and perfused 15 min after injection. Scale bar, $400 \mu \mathrm{m}$. Higher-magnification images of each single staining are shown. Scale bar, $150 \mu \mathrm{m}$. $\boldsymbol{B}$, Double immunostaining for pS235/236-rpS6 and GFP in coronal sections of the striatum from Drd1a- (i) and Drd2-EGFP (ii) mice treated with D-amph (10 mg/kg) and killed $15 \mathrm{~min}$ after injection Yellow arrowheads indicate GFP/pS235/236-rpS6-positive MSNs. C, Double immunostaining for pS235/236-rpS6 and ChAT (i), Parvalbumin (ParV) (ii), nNOS (iii), and calretinin (CalR) (iv) in coronal sections of the striatum from mice treated with D-amph (10 mg/kg) and perfused $15 \mathrm{~min}$ after injection. Scale bar in $\boldsymbol{B}$ and $\boldsymbol{C}, 35 \mu \mathrm{m}$. DStr, Dorsal striatum; Acb, nucleus accumbens; $c_{\text {, }}$ corpus callosum; ac, anterior commissure; v, ventricle.

equally enhanced in striosome and matrix compartments of the dorsolateral striatum (Fig. $2 A$ ).

We next examined the cell-type-specific localization of pS235/ 236-rpS6 after a single D-amph administration by using Drd1a- and Drd2-EGFP-transgenic mice to identify striatonigral and striatopallidal MSNs, respectively (Valjent et al., 2009). We found that the increase in pS235/236-rpS6 induced by acute D-amph administration occurred predominantly in D1R-containing MSNs 
A



SCH23390 + d-amph

B

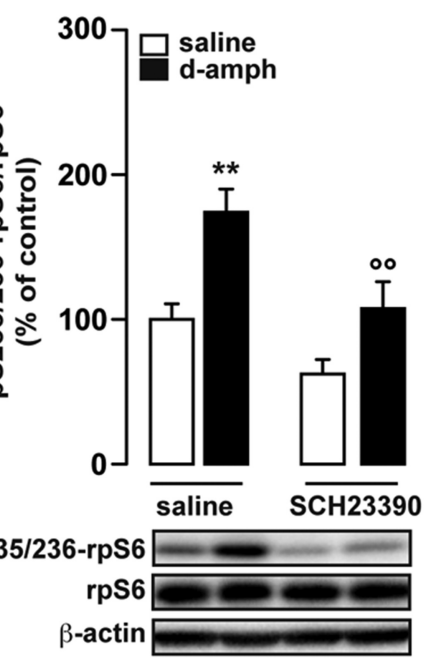

C

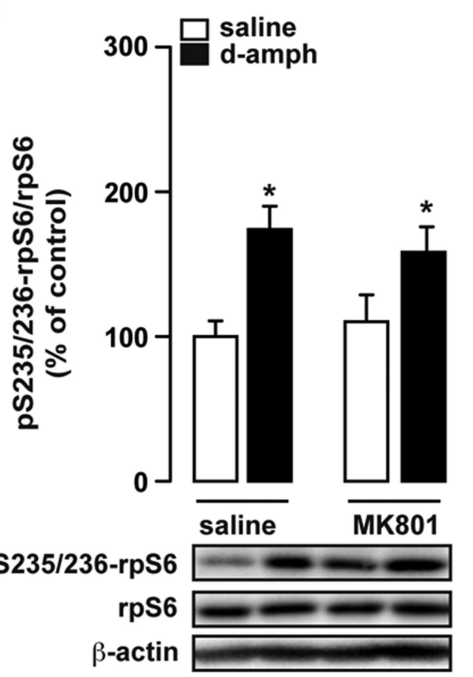

E

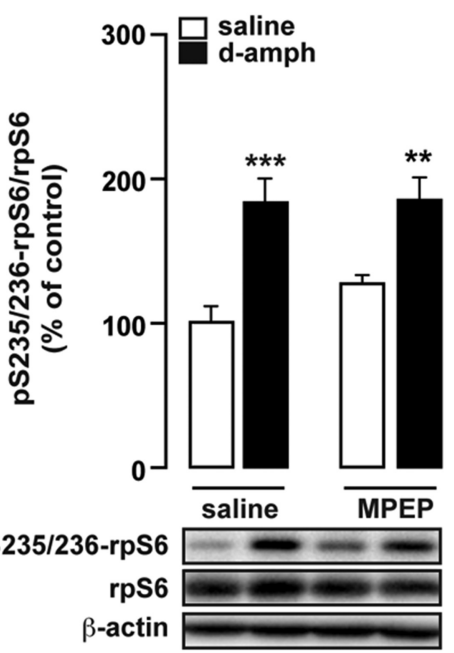

D
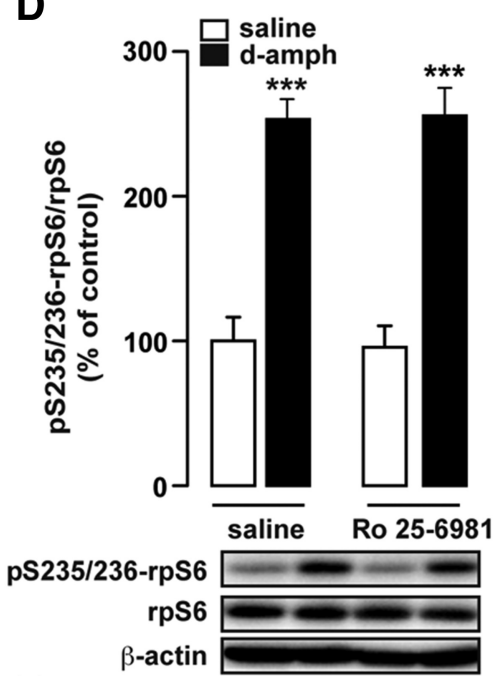

$\mathbf{F}$

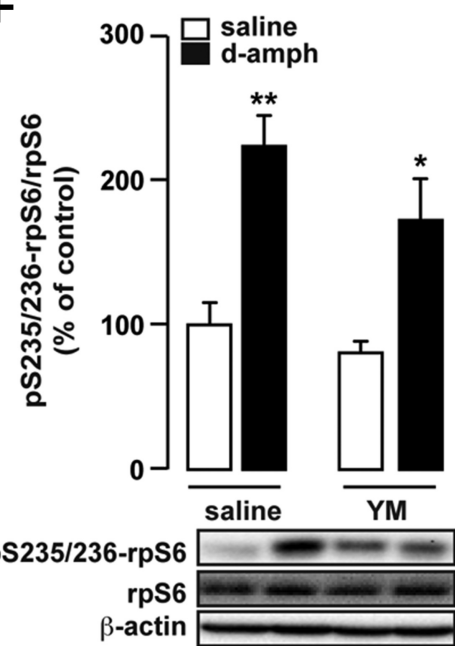

Figure 3. D-amph-induced rpS6 phosphorylation depends on D1R but not NMDAR and mGluR1/5-R stimulation. $\boldsymbol{A}, \mathrm{pS} 235 / 236$ rpS6 immunostaining of striatal coronal slices from mice perfused $15 \mathrm{~min}$ after D-amph $(10 \mathrm{mg} / \mathrm{kg})$ and pretreated 30 min before with saline (left) or the D1/D5-R antagonist SCH23390 (0.15 mg/kg) (right). Scale bar, $800 \mu \mathrm{m}$. $\boldsymbol{B}-\boldsymbol{F}$, Quantified (top) and representative (bottom) Western blot analyses of pS235/236-rpS6 (normalized to rpS6) from mice killed 15 min after D-amph (10 $\mathrm{mg} / \mathrm{kg}$ ) treatment and pretreated 30 min before with SCH23390 $(0.15 \mathrm{mg} / \mathrm{kg} ; \boldsymbol{B})$, the NMDAR antagonist MK801 $(0.1 \mathrm{mg} / \mathrm{kg} ; \boldsymbol{C}$, the NR2B subunit of NMDAR antagonist Ro 25-6981 (10 mg/kg; D), the mGluR5 antagonist MPEP (15 mg/kg; $\boldsymbol{E})$, or the mGluR1 antagonist YM298198 (YM, $15 \mathrm{mg} / \mathrm{kg} ; \boldsymbol{F}$ ). Results are represented as mean \pm SEM and by one-way ANOVA followed by NewmanKeuls test ( $n=6$ mice/group). ${ }^{*} p<0.05,{ }^{* *} p<0.01,{ }^{* * *} p<0.001$ (D-amph vs saline), ${ }^{\circ 0} p<0.01$ (antagonist pretreatment vs D-amph). DStr, Dorsal striatum; Acb, nucleus accumbens; (x, cortex; cc, corpus callosum; ac, anterior commissure.

(Fig. 2Bi-Bii). In contrast, no pS235/236-rpS6 immunoreactivity was found in cholinergic interneurons identified with a choline acetyltransferase antibody (ChAT; Fig. 2Ci), nor in the different classes of GABAergic interneurons identified with parvalbumin (ParV; Fig. 2Cii), neuronal nitric oxide synthase (nNOS; Fig. 2Ciii), and calretinin (CalR; Fig. 2Civ). Altogether, these results show that $\mathrm{D}$-amph-induced rpS6 phosphorylation occurred selectively in D1R-positive striatonigral MSNs, preferentially in the patches of the ventromedial striatum and in both patch and matrix compartments of the dorsolateral striatum.

D-amph induces a massive release of DA in the striatum (Cadoni et al., 1995). To assess whether D1Rs were involved in the D-amph-induced rpS6 phosphorylation, the D1/D5R antagonist SCH23390 was administered before D-amph. As illustrated by immunofluorescence (Fig. $3 A$ ) and Western blot analysis (Fig. $3 B$ ), the blockade of D1Rs strongly reduced the D-amph-induced phosphorylation of rpS6 and slightly reduced its basal level. Because some effects of psychostimulant drugs involve stimulation of glutamate receptors (Valjent et al., 2005; Anderson et al., 2008; Miller et al., 2014), we next addressed the possible contribution of glutamatergic transmission. Pretreatment of mice with the NMDAR antagonist MK801 or the NR2B subunit antagonist Ro 25-6981 did not alter basal or D-amph-induced rpS6 phosphorylation (Fig. 3C,D). Similar results were obtained when mice were pretreated with the mGluR5 or mGluR1 antagonists MPEP or YM298198, respectively (Fig. 3 E,F). Together, our data demonstrate that the in vivo stimulation of dopamine transmission by acute D-amph markedly increases the phosphorylation of rpS6 through D1R stimulation in striatonigral MSNs in both crude and synaptoneurosomal fractions in a time- and anatomical compartmentdependent manner.

D-amph-induced rpS6 phosphorylation is independent of mTORC1, ERK, and PKC signaling

rpS6 is a structural component of the ribosome that can be phosphorylated directly by several protein kinases, including p70S6K (Krieg et al., 1988; Bandi et al., 1993; Meyuhas, 2008), p90S6K (Roux et al., 2007), PKC (House et al., 1987), and PKA (Moore et al., 2009; Valjent et al., 2011; Yano et al., 2014). Therefore, we aimed to identify the kinase responsible for the phosphorylation of rpS6 induced by acute D-amph in striatonigral MSNs. 
A

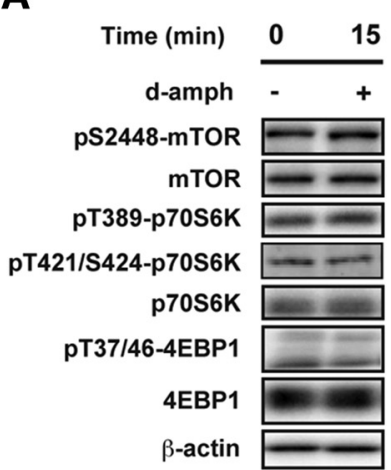

C

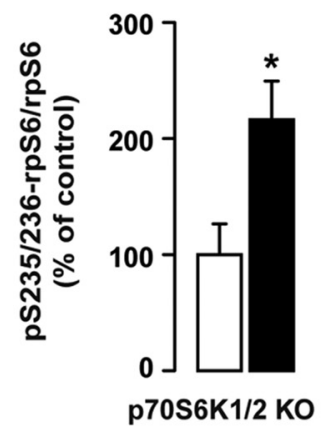

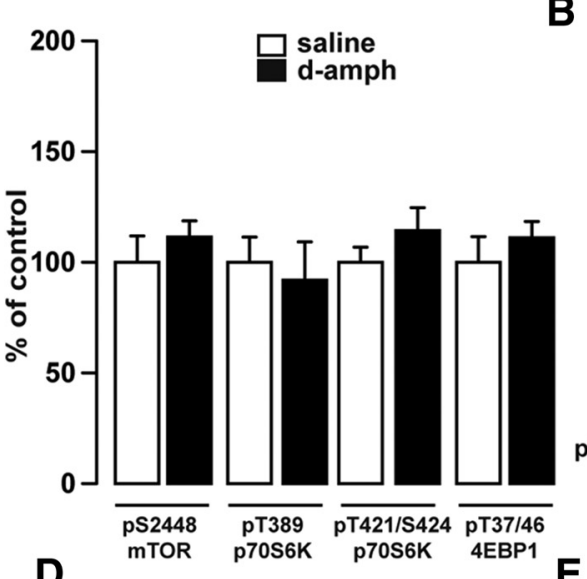

D

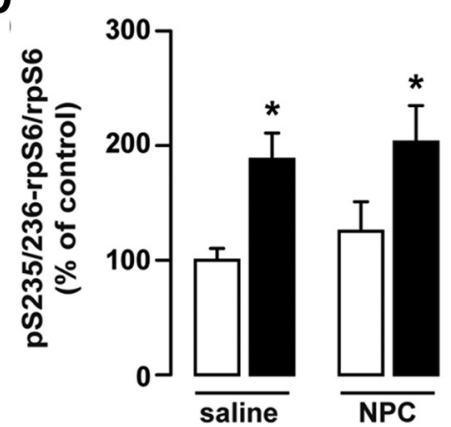

B

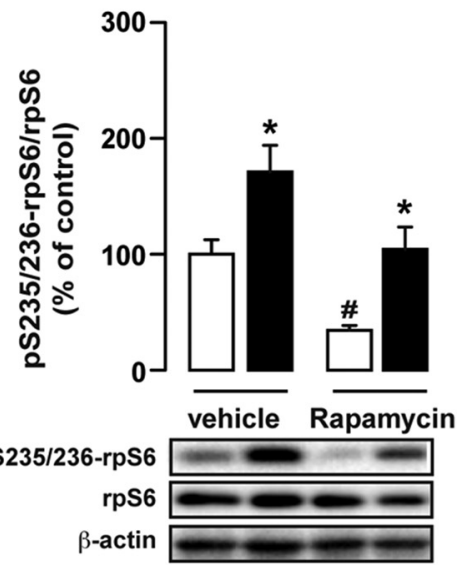

E

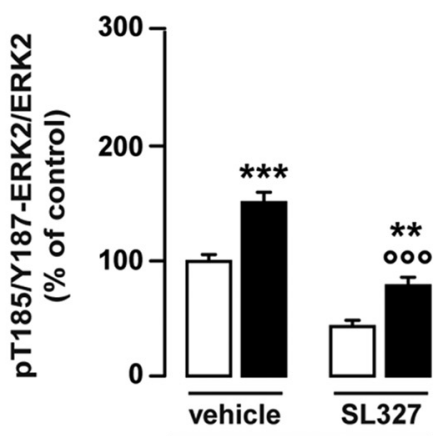

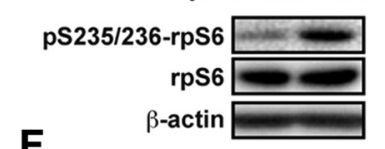

F

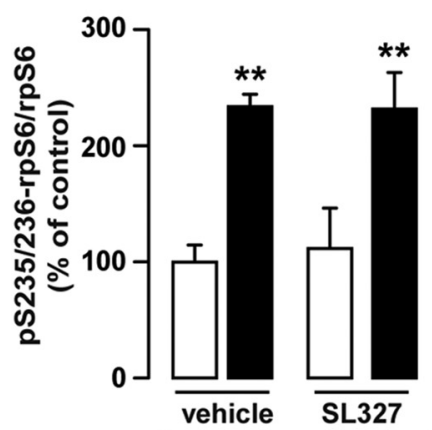

pS235/236-rpS6 $\div$

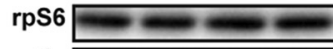

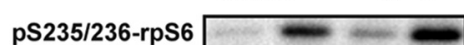

rps6 $\approx-\infty$

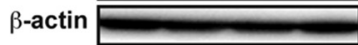

G

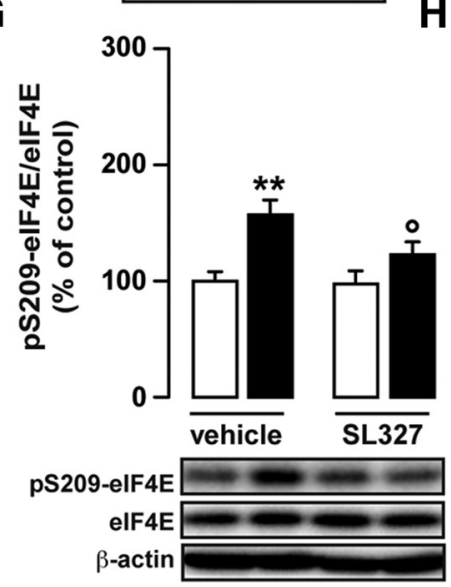

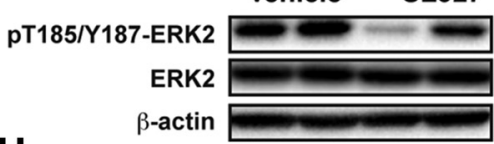

H

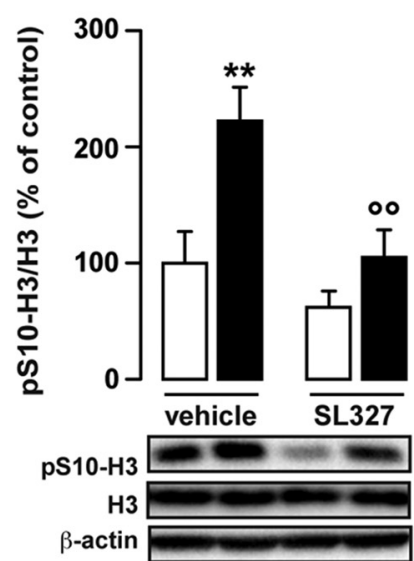

Figure 4. D-amph-induced rpS6 phosphorylation is independent of mTORC1/p70S6K1/2, PKC and ERK signaling. $A$, Representative Western blots (left) and quantified signals (right) of whole striatal lysates from mice killed $15 \mathrm{~min}$ after saline or D-amph $(10 \mathrm{mg} / \mathrm{kg})$ treatment. The level of each phospho-protein was normalized to the respective total protein. Results are represented as mean \pm SEM ( $n=6$ mice/group). $B$, Quantified (top) and representative (bottom) Western blot analyses of pS235/236-rpS6 (normalized to rpS6) from mice killed $15 \mathrm{~min}$ after $\mathrm{D}$-amph (10 mg/kg) treatment and pretreated with the mTORC1 inhibitor rapamycin (2 injections of $10 \mathrm{mg} / \mathrm{kg}, 3 \mathrm{~h}$ and $30 \mathrm{~min}$ prior D-amph). Results are represented as mean \pm SEM and by one-way ANOVA followed by Newman-Keuls test ( $n=6$ mice/group). ${ }^{*} p<0.05$ (D-amph vs saline), $\# p<0.05$ (rapamycin vs vehicle). C, Quantified (top) and representative Western blots (bottom) for pS235/236-rpS6 (normalized to rpS6) of whole striatal lysates from p7056K1/2 double-knock-out (KO) mice that received saline or D-amph (10 mg/kg) and were killed 15 min after injection. Data are expressed as a percentage of saline-treated mice. Results are represented as mean \pm SEM. ${ }^{*} p<0.05$ by Student's $t$ test ( $n=4$ mice/group). $D$, Quantified (top) and representative (bottom) Western blot analyses of pS235/236-rpS6 (normalized to rpS6) from mice killed $15 \mathrm{~min}$ after D-amph (10 mg/kg) treatment and pretreated with the PKC inhibitor NPC 15437 (NPC, $8 \mathrm{mg} / \mathrm{kg}, 30 \mathrm{~min} \mathrm{prior} \mathrm{D-amph).}$ $\boldsymbol{E}-\boldsymbol{H}$, Quantified (top) and representative (bottom) Western blot analyses of pT185/Y187-ERK2 (E), pS235/236-rpS6 (F), pS209-elF4E (G), and pS10 -H3 (H) (all normalized to the respective total form) from mice killed $15 \mathrm{~min}$ after D-amph (10 mg/kg) treatment and pretreated with the MEK inhibitor SL327 ( $50 \mathrm{mg} / \mathrm{kg}, 60 \mathrm{~min}$ before $\mathrm{D}$-amph). Results are represented as mean \pm SEM and by one-way ANOVA followed by Newman-Keuls test ( $n=6$ mice/group). ${ }^{*} p<0.05,{ }^{* *} p<0.01,{ }^{* * *} p<0.001$ (D-amph vs control), ${ }^{\circ} p<0.05,{ }^{\circ 0} p<0.01,{ }^{000} p<0.001$ (drug $+\mathrm{D}$-amph vs vehicle $+\mathrm{D}$-amph).

Because mTORC1/p70S6K signaling has been proposed to be the predominant pathway modulating rpS6 phosphorylation (Dufner and Thomas, 1999), we analyzed the activity of mTORC1 signaling in the striatum after D-amph administration. No difference was observed in the phosphorylation state of pS2448-mTOR or its downstream targets pT389-p70S6K1/2, pT421/S424p70S6K1/2, and pT37/46 -4EBP1 after a single D-amph administration (Fig. 4A). To further confirm the lack of involvement of mTORC1 signaling and to rule out the possibility that basal phospho-p70S6K1/2 levels could still mediate the rpS6 phosphoryla- 
tion induced by D-amph, we used pharmacological and genetic approaches. We found that D-amph-induced S235/236-rpS6 phosphorylation was preserved in mice pretreated with the mTORC1 inhibitor rapamycin (Fig. $4 B$ ), as well as in p70S6K1/2 double knock-out mice (Fig. 4C). However, basal levels of pS235/ 236-rpS6 were decreased after rapamycin pretreatment, indicating that mTORC1 is involved in the basal phosphorylation of rpS6 in striatal neurons.

Through a non-canonical pathway, D1R has been proposed to signal via Gq/phospholipase C (Felder et al., 1989; Nishi et al., 2011), which leads to PKC activation. Because PKC has been reported to phosphorylate rpS6 in vitro (House et al., 1987; Yano et al., 2014), we tested its role in striatal neurons. We found that blockade of PKC by NPC 15437 did not affect the D-amphinduced increase in pS235/236-rpS6 (Fig. 4D).

Because D-amph activates ERK (Valjent et al., 2005) (Fig. 4E), which can induce rpS6 phosphorylation through p90RSK (Roux et al., 2007), we tested its role using the mitogen-activated protein/extracellular signal-regulated kinase kinase inhibitor (MEK) SL327, given prior D-amph administration. The blockade of ERK signaling (Fig. 4E) did not prevent D-amph-induced rpS6 phosphorylation (Fig. $4 F$ ), whereas it diminished the increase in the phosphorylation of ERK targets, the eukaryotic initiation factor 4E (eIF4E) (Fig. 4G), and the histone H3 (Fig. 4H) after D-amph administration. Moreover, D-amph did not modify the phosphorylation state of pT573-p90RSK, the ERK downstream target responsible of rpS6 phosphorylation (saline $100 \pm 4.2, n=5$ and D-amph $99.5 \pm 6.6, n=6$ mice/group). Together, these data showed that the in vivo striatal S235/236-rpS6 phosphorylation induced by $\mathrm{D}$-amph selectively in striatonigral MSNs is independent of mTORC1/p70S6K, ERK/p90RSK, and PKC signaling.

\section{Goolf/cAMP/PKA/DARPP-32 signaling mediates rpS6 phosphorylation in MSNs}

Activation of D1Rs stimulates the heterotrimeric G-protein G $\alpha$ olf (encoded by the gene Gnal), which is positively coupled to adenylyl cyclase (AC), triggering cAMP production and PKA activation (Hervé et al., 1993). Because cAMP/PKA signaling has been proposed recently to regulate rpS6 phosphorylation (Moore et al., 2009; Valjent et al., 2011; Bonito-Oliva et al., 2013), we first analyzed rpS6 phosphorylation at S235/236 by immunofluorescence along the rostrocaudal and ventromedial axis in parahorizontal sections of wild-type and $\mathrm{Gnal}^{+/-}$mice treated with saline or D-amph. Although low, pS235/236-rpS6 immunoreactivity was still observed in the striosomes at the most rostral levels, D-amph-induced pS235/236-rpS6 phosphorylation was strongly reduced throughout the striatum in $\mathrm{Gnal}^{+/-}$mice (Fig. 5A,B).

To further assess the involvement of enhanced cAMP/PKA signaling in striatal S235/236-rpS6 phosphorylation, we performed two additional experiments. We first injected papaverine, an inhibitor of PDE10a phosphodiesterase (Nishi et al., 2008), to increase cAMP levels artificially. Papaverine induced a robust increase of pS235/236-rpS6 in the mouse dorsal striatum (Fig. $6 A$ ), which occurred in both striatonigral and striatopallidal MSNs (Fig. 6B). Because a previous study reported that PKA is able to activate p70S6K1/2 robustly, which in turn phosphorylates rpS6 (Cass et al., 1999), we assessed the involvement of the mTORC1/p70S6K pathway in the pS235/236-rpS6 induced by papaverine. Similar to what we observed with D-amph, papaverine did not change the phosphorylation state of pS2448-mTOR and its substrates pT389-p70S6K, pT421/S424-p70S6K, and pT37/46-4EBP1 (Fig. 6C), and papaverine-induced pS235/236-

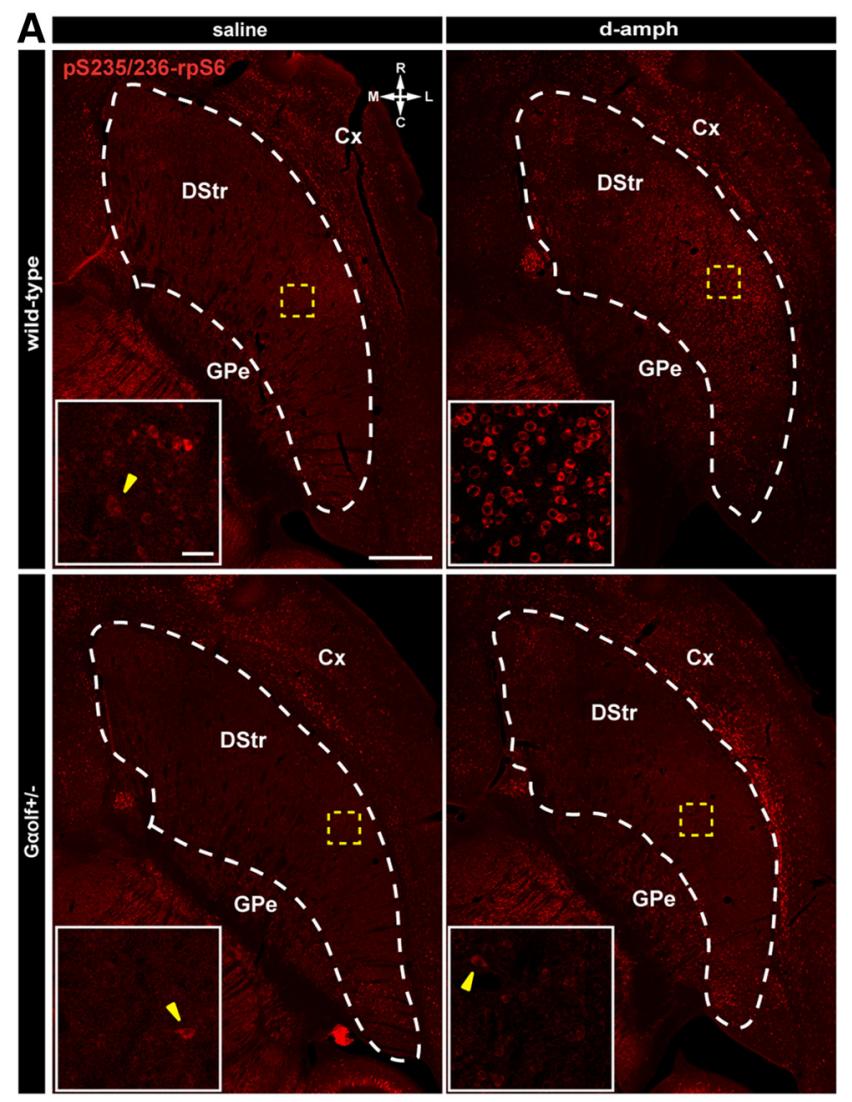

$\mathbf{B}$

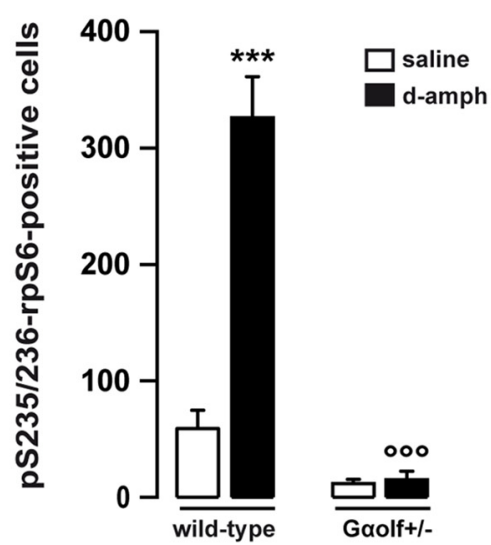

Figure 5. G $\alpha$ olf/CAMP/PKA signaling regulates striatal rpS6 phosphorylation. $\boldsymbol{A}, \mathrm{pS} 235 /$ 236-rpS6 immunostaining of striatal parahorizontal slices from wild-type or $G \alpha$ olf $^{+/-}$mice perfused $15 \mathrm{~min}$ after saline or D-amph (10 mg/kg) treatment. Scale bar, $450 \mu \mathrm{m}$. Insets, High magnification of the areas delineated by the yellow stippled rectangle. Yellow arrowheads indicate ChAT interneurons. Scale bar, $30 \mu \mathrm{m}$. DStr, Dorsal striatum; Cx, cortex; GPe, external globus pallidus; R, rostral; C, caudal; M, medial; L, lateral. B, Quantification of pS235/236-rpS6positive cells in an equal-sized region of interest of the striatal parahorizontal slices from wildtype or $\mathrm{G} \alpha$ olf $^{+/-}$mice perfused $15 \mathrm{~min}$ after saline or D-amph $(10 \mathrm{mg} / \mathrm{kg})$ treatment. Results are represented in as a mean \pm SEM and by one-way ANOVA followed by Newman-Keuls test ( $n=3-4$ mice/group). ${ }^{* * *} p<0.001$ (D-amph vs control), ${ }^{\circ 0} p<0.001$ (wild-type vs G $\alpha$ olf $^{+/-}$mice).

rpS6 was unchanged in p70S6K1/2 double knock-out mice (Fig. $6 D)$, suggesting that the analyzed phenomenon is mTORC1/ p70S6K independent. Consistent with the absence of pT185/ Y187-ERK2 modulation by papaverine (Fig. $6 E, F$ ), we confirmed the lack of involvement of ERK signaling because papaverineinduced rpS6 phosphorylation was still present in SL327pretreated mice (Fig. $6 E-G$ ). We next performed ex vivo 
A
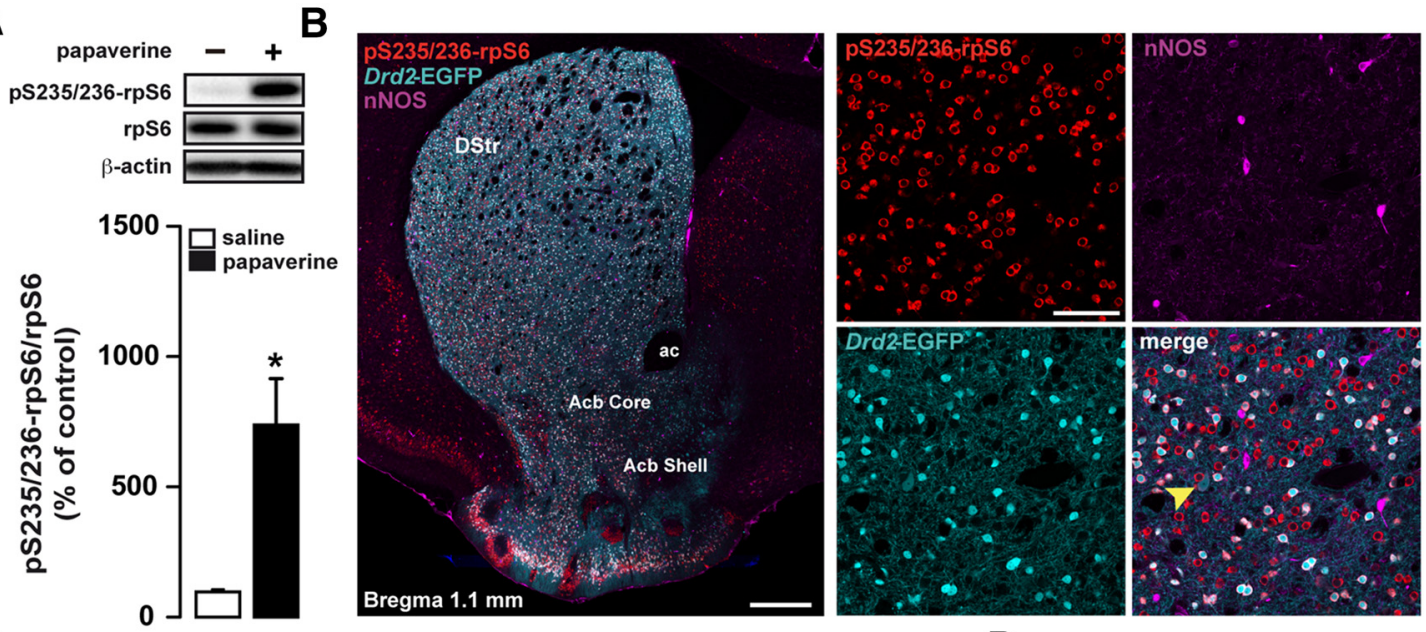

C
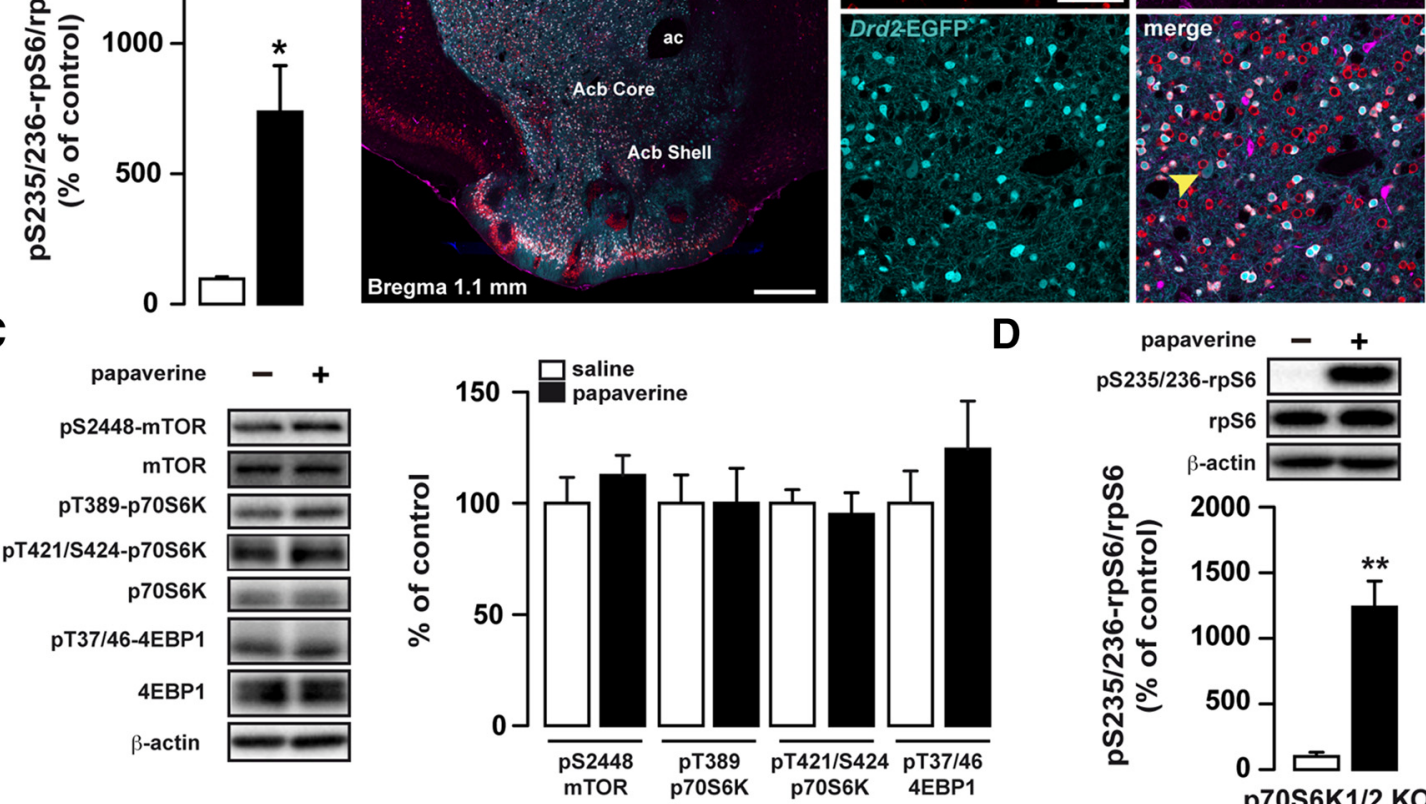

D

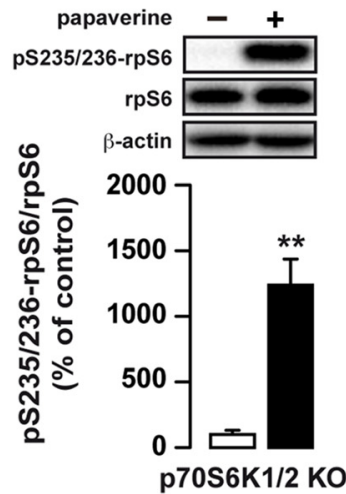

E
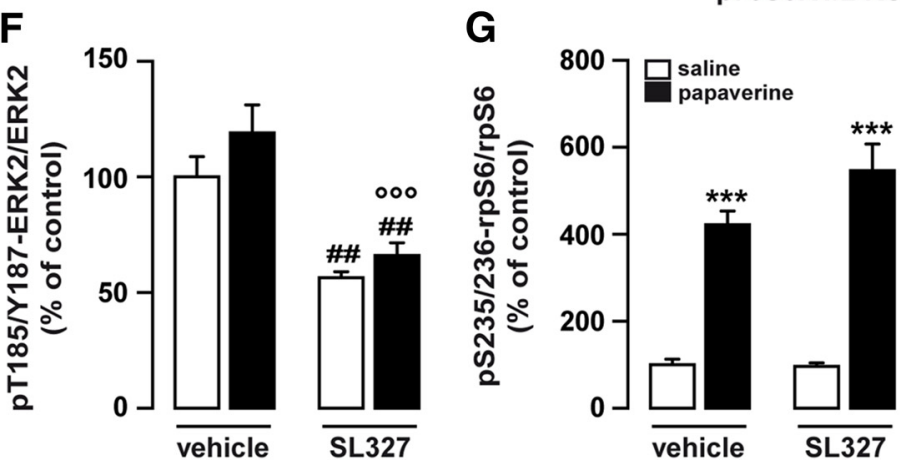

Figure 6. Inhibition of CAMP degradation by papaverine increases striatal rpS6 phosphorylation independently of mTORC1/p70S6K1/2 signaling. A, Representative (top) and quantified (bottom) Western blot data of pS235/236-rpS6 (normalized to rpS6) in whole striatal lysates from mice that received a single injection of saline or papaverine (30 mg/kg) and were killed at $15 \mathrm{~min}$ after injection. Results are represented as mean \pm SEM. ${ }^{*} p<0.05$ by Student's test ( $n=5$ mice/group). $B$, Triple immunostaining for pS235/236-rpS6 (red), GFP (cyan) and nNOS (magenta) in striatal coronal sections from Drd2-EGFP mice treated with papaverine $(30 \mathrm{mg} / \mathrm{kg}$ ) and perfused $15 \mathrm{~min}$ after injection. Scale bar, $400 \mu \mathrm{m}$. Higher-magnification images of each single staining are shown. Scale bar, $150 \mu \mathrm{m}$. Note the lack of costaining between pS235/236-rpS6 and ChAT-positive interneurons (yellow arrowhead). C, Representative Western blots (left) and quantified signals (right) of whole striatal lysates from mice killed $15 \mathrm{~min}$ after saline or papaverine $(30 \mathrm{mg} / \mathrm{kg})$ treatment. The level of each phosphoprotein was normalized to the respective total protein. Results are represented as mean \pm SEM ( $n=5$ mice/group). D, Representative (top) and quantified (bottom) Western blot data of pS235/236-rpS6 (normalized to rpS6) of whole striatal lysates from p70S6K1/2 double knock-out (KO) mice that received saline or papaverine $(30 \mathrm{mg} / \mathrm{kg})$ and were killed at $15 \mathrm{~min}$ after injection. Data are expressed as a percentage of saline-treated mice. Results are represented as mean \pm SEM. ${ }^{* *} p<0.01$ by Student's $t$ test ( $n=4$ mice/group). $\boldsymbol{E}$, Representative Western blots of pT185/Y187-ERK2, ERK2, pS235/236-rpS6, and rpS6 from mice killed 15 min after papaverine ( $30 \mathrm{mg} / \mathrm{kg}$ ) treatment and pretreated with vehicle or the MEK inhibitor SL327 (50 mg/kg, 60 min before papaverine). F, G, Quantified Western blot analyses of pT185/Y187-ERK2 $(\boldsymbol{F})$ and pS235/236-rpS6 (G) (all normalized to the respective total form) from mice killed $15 \mathrm{~min}$ after papaverine ( $30 \mathrm{mg} / \mathrm{kg}$ ) treatment and pretreated with the MEK inhibitor SL327 (50 mg/kg, 60 min prior papaverine). Results are represented as mean \pm SEM and by one-way ANOVA followed by Newman-Keuls test ( $n=6$ mice/group). \#\#p $<0.01<0.01$ (SL327 vs vehicle) ${ }^{* * *} p<0.001$ (papaverine vs control), ${ }^{000} p<0.001$ (vehicle + papaverine vs SL327 + papaverine). DStr, Dorsal striatum; Acb, nucleus accumbens; ac, anterior commissure.

stimulation of cAMP production using the AC activator forskolin in mouse striatal slices and found a marked increase in S235/236-rpS6 phosphorylation, which was attenuated with the pretreatment of Rp-cAMP (Fig. 7A) to the same extent as the PKA-dependent DARPP-32 phosphorylation at T34 site (Fig. 7B). Increased cAMP/ PKA signaling has been reported previously to stimulate the activity of the ERK pathway (Valjent et al., 2005). However, the pretreatment of striatal slices with the MEK inhibitor U0126 did not prevent the forskolin-induced increase in pS235/236-rpS6, allowing us to rule out the contribution of ERK signaling in this response (Fig. $7 C$ ). Altogether, these results show that enhancement of striatal cAMP levels, either by stimulating its production with forskolin or by inhibiting its degradation with papaverine, induced rpS6 phosphorylation via PKA. 
A

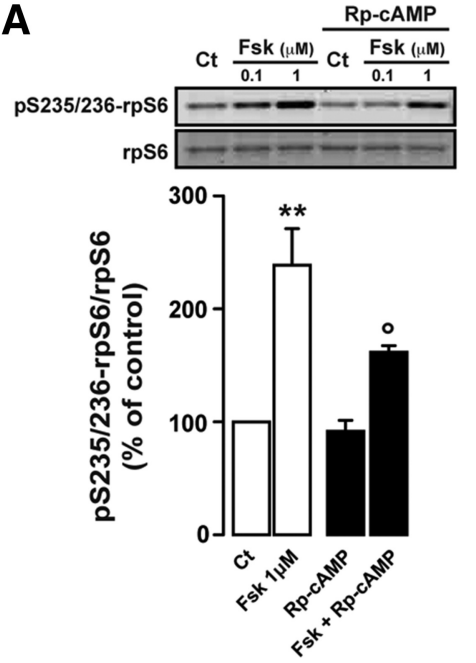

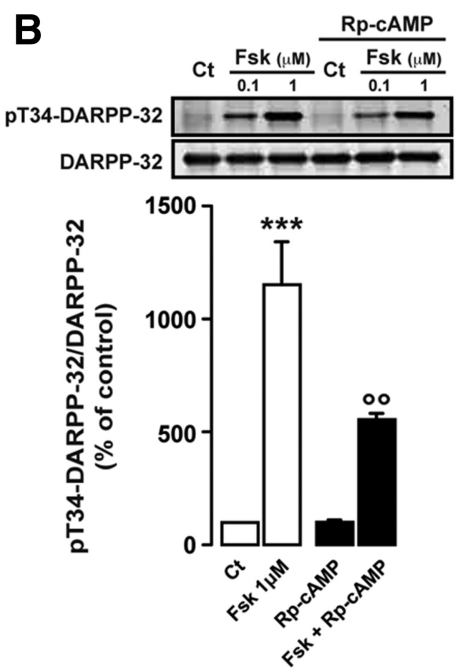



Figure 7. Stimulation of cAMP production by forskolin increases striatal rpS6 phosphorylation through PKA signaling. $A, B$, Representative (top) and quantified (bottom) Western blot data of the effect of the PKA inhibitor Rp-CAMP on forskolin (Fsk) (0.1 or $1 \mu \mathrm{M}$ ) induced pS235/236-rpS6 (normalized to rpS6) (A) and pT34-DARPP-32 (normalized to DARPP-32) compared with control (Ct) group in mouse striatal slices. Results are represented as mean \pm SEM and by one-way ANOVA followed by Newman-Keuls test $(n=3) .{ }^{* *} p<0.01,{ }^{* * *} p<0.001$ (Fsk vs $C t$ ), ${ }^{\circ} p<0.05,{ }^{\circ} p<$ 0.01 (Fsk vs Fsk + Rp-CAMP). C, Representative Western blot analyses of the effect of the MEK inhibitor U0126 on forskolin (Fsk) (0.1 or $1 \mu$ M)-induced pT34-DARPP-32, pT202/Y204/T185/Y187ERK1/2, and pS235/236-rpS6 (normalized to their respective total forms) compared with Ct group in mouse striatal slices.

In the striatum, one of the major PKA substrates is DARPP32, which is highly expressed in MSNs and acts as a potent inhibitor of PP-1 (Hemmings et al., 1984; Greengard, 2001). Interestingly, several studies suggest that PP-1 could be one of the phosphatases dephosphorylating rpS6 (Belandia et al., 1994; Hutchinson et al., 2011). To address the role of PKA-mediated phosphorylation of DARPP-32 and of the resulting inhibition of PP-1, we used DARPP-32 T34A mutant mice in which PKAmediated regulation of DARPP-32 is silenced (Svenningsson et al., 2003). Consistent with the immunofluorescence analysis performed in $\mathrm{Gnal}^{+/-}$mice, S235/236-rpS6 phosphorylation was almost absent in the entire striatum of DARPP-32 T34A mutant mice treated with $\mathrm{D}$-amph (Fig. $8 A, B$ ) and only low immunoreactivity was observed in the striosomes of the rostral part (Fig. $8 A$ ). These data indicate that D-amph-induced sustained S235/ 236-rpS6 phosphorylation in striatonigral MSNs requires G $\alpha$ olf/ PKA/DARPP-32/PP-1 signaling.

To summarize, we found that D-amph administration through $\mathrm{D} 1 \mathrm{R} / \mathrm{G} \alpha$ olf stimulation induces cAMP production, which triggers rpS6 phosphorylation via PKA/DARPP-32/PP-1 signaling (Fig. $8 C$ ). In agreement, in vivo and ex vivo increase in cAMP tone by papaverine and forskolin, respectively, is correlated with enhanced p-rpS6 levels (Fig. 8C), pointing to cAMP/ PKA signaling as the major actor triggering rpS6 phosphorylation in striatal MSNs.

PKA-dependent rpS6 phosphorylation is uncorrelated with changes in global and TOP mRNA translation in striatonigral and striatopallidal MSNs

It is now well established that rpS6 phosphorylation is not involved in the control of global protein synthesis in liver (Ruvinsky et al., 2005), but this issue is still a matter of debate in the CNS (Klann et al., 2004). Therefore, we tested whether the D-amphinduced increase in rpS6 phosphorylation could affect overall translation in the striatum. To measure translation initiation rates, we performed polysome profiling of striatal lysates from mice acutely treated with saline or D-amph $(10 \mathrm{mg} / \mathrm{kg})$. Remarkably, despite the high increase of pS235/236-rpS6 induced by
D-amph, no difference was observed in the polysome profiles of saline versus D-amph-treated mice (Fig. 9A).

Because polysome profiling is not a measurement of de novo protein synthesis, but rather a representation of the steady-state ribosomes engaged in translation, we adapted a recently developed novel technique called the ribopuromycylation method (David et al., 2012). This approach is based on the labeling of active protein synthesis using anti-puromycin antibodies recognizing puromycin incorporated into nascent peptidic chains (see Materials and Methods). Because it is the first time that this approach has been used in intact brain tissue, we first validated the specificity of the anti-puromycin antibody (Fig. 9B). Incubation with harringtonin, an inhibitor of translation initiation, decreased puromycin immunoreactivity, confirming that the technique is sensitive enough to detect changes in active translation (Fig. 9C). Moreover, our results suggest that, in the striatum, not all of the polyribosomes are stalled at the level of elongation, in contrast to what has been demonstrated recently in dissociated rat primary hippocampal neuron culture using the ribopuromycylation method (Graber et al., 2013). Western blot analysis of whole striatal lysates revealed no differences in puromycin incorporation between saline- and D-amph-treated mice killed $15 \mathrm{~min}$ (saline $100 \pm 12.4$ and D-amph $114 \pm 9.9, n=16$ mice/group) or 1 or $2 \mathrm{~h}$ after injection (Fig. 9D). In agreement with the polysome profile analysis, the puromycin-based assay indicated that global protein synthesis in the striatum was not altered by D-amph. The absence of correlation between pS235/236-rpS6 phosphorylation and global mRNA translation was further emphasized by the plot correlation analysis between p-rpS6 and puromycin incorporation in the same samples from mice treated with saline or D-amph $\left(R^{2}=0.023\right.$; Fig. 9E). We also performed puromycin labeling in synaptoneurosomal fractions of mice treated with saline or D-amph. No changes of overall protein synthesis were observed, suggesting that $\mathrm{D}$-amph does not alter the translation rate locally at the synaptic level (Fig. 9F).

Translation initiation involves soluble proteins, including eukaryotic initiation factors (eIFs) (Sonenberg and Hinnebusch, 

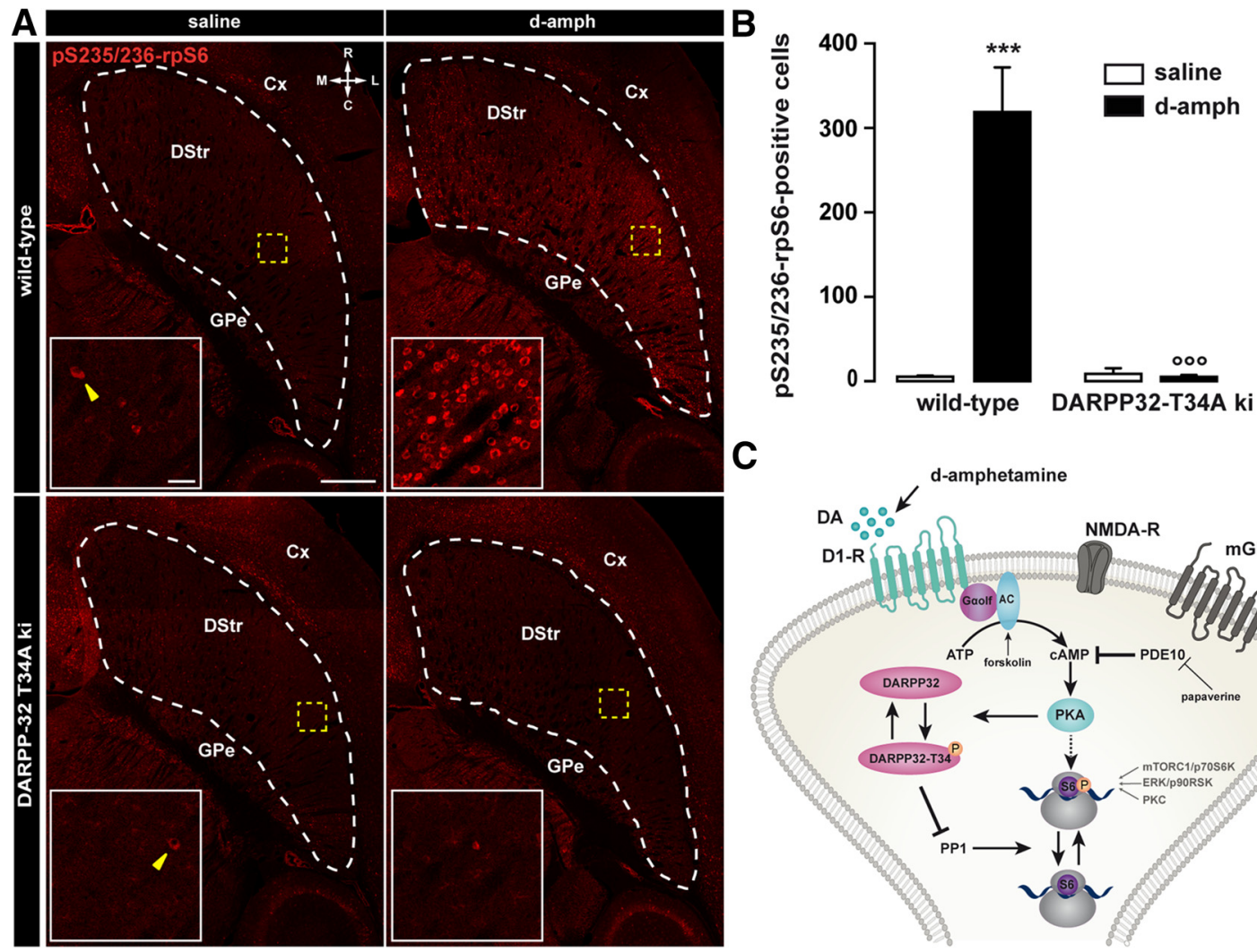

\section{C}

Figure 8. D-amph-induced rpS6 phosphorylation in MSNs requires inhibition of PP-1. A, pS235/236-rpS6 immunostaining in striatal parahorizontal slices from wild-type or DARPP-32 T34A mice perfused $15 \mathrm{~min}$ after saline or D-amph (10 mg/kg) treatment. Scale bar, $450 \mu \mathrm{m}$. Insets, High magnification of the areas delineated by the yellow stippled rectangle. Yellow arrowheads indicate ChAT-positive interneurons. Scale bar, $30 \mu \mathrm{m}$. DStr, Dorsal striatum; CX, cortex; GPe, external globus pallidus; $\mathrm{R}$, rostral; C, caudal; M, medial; L, lateral. B, Quantification of pS235/236-rpS6-positive cells in an equal-sized region of interest of the striatal parahorizontal slices from wild-type or DARPP-32 T34A knock-in mice (DARPP-32 T34A ki) perfused $15 \mathrm{~min}$ after saline or D-amph (10 mg/kg) treatment. Results are represented in as mean \pm SEM and by one-way ANOVA followed by Newman-Keuls test $\left(n=3-4\right.$ mice/group). ${ }^{* * *} p<0.001$ (D-amph vs control), ${ }^{000} p<0.001$ (wild-type vs DARPP-32 T34A ki). C, Diagram depicting the signaling pathway involved in rpS6 phosphorylation in the striatum in response to acute D-amph administration. D-amph through the stimulation of D1R, but not NMDAR or mGluR1/5Rs, induces rpS6 phosphorylation in D1R-expressing MSNs. D1R coupled G-protein G $\alpha$ olf triggers adenylyl cyclase (AC) activity and thus stimulates cAMP signaling. Stimulation of CAMP production by forskolin or inhibition of CAMP degradation by papaverine (a PDE10a inhibitor) is sufficient to increase rpS6 phosphorylation in the striatum. Increased cAMP levels lead to the activation of PKA, which phosphorylates DARPP-32 at T34 site. In turn, DARPP-32 inhibits PP-1 and promotes rpS6 phosphorylation via the suppression of its dephosphorylation. The studied phenomenon is independent of mTORC1/p70S6K1/2, ERK/p90RSK, and PKC signaling.

2009). Phosphorylation of several eukaryotic initiation factors, such as eIF4E and eIF4G, positively correlates with increased translation rates (Mahoney et al., 2009). Although we observed a slight increase in pS209-eIF4E (Fig. 4G), pS1108-eIF4G remained unchanged after D-amph administration (Table 2). Moreover, D-amph did not change the phosphorylation of eIF2 $\alpha$, which is known to inhibit translation (Costa-Mattioli et al., 2009; Table 2). After the initiation step, the ribosome proceeds with translation elongation, which involves eukaryotic elongation factors (eEFs). We assessed the phosphorylation state of eEF2, the phosphorylation of which by the eEF2 kinase interrupts translation elongation. We did not observe differences in pT56-eEF2 in saline- versus D-amph-treated mice (Table 2). Together, these data are in agreement with the polysome profiling and the puromycin-based assay, demonstrating that D-amph has no significant effect on overall translation in the striatum.

Because D-amph induces pS235/236-rpS6 phosphorylation predominantly in D1R-containing MSNs, which account for almost $50 \%$ of striatal neurons, the lack of overall protein synthesis stimulation observed in crude striatal homogenates could be masked by the effect of other cell types. To circumvent this limitation, we administered puromycin intracerebroventricularly in Drd2-EGFP mice to examine translational changes selectively in D1R- or D2R-containing MSNs. The specificity of anti- puromycin immunofluorescence was validated by verifying the lack of immunoreactivity in mice that received an infusion of the vehicle (Fig. 9G). In agreement with the Western blot analyses, no differences in puromycin immunostaining were found between saline- and D-amph-treated mice (Fig. 9H-J), Moreover, similar translation rates were observed in both striatonigral and striatopallidal MSNs (Fig. 9I,J). Finally, the triple immunofluorescence analysis of pS235/236-rpS6, GFP, and puromycin confirmed the lack of correlation between pS235/236-rpS6 phosphorylation and puromycin incorporation because some pS235/236-rpS6stained MSNs were positive (white arrowhead) and some were negative (yellow arrowhead) for puromycin (Fig. 9H).

Although the causal relationship between rpS6 phosphorylation and TOP mRNA translation has been refuted (Tang et al., 2001; Stolovich et al., 2002), recent studies reported a correlation between enhanced rpS6 phosphorylation and the synthesis of the TOP mRNA-encoded proteins rpS6 and the eukaryotic translation elongation factor $1 \mathrm{~A}$ ( $\mathrm{eEF} 1 \mathrm{~A})$ in the hippocampus (Tsokas et al., 2005; Antion et al., 2008). Therefore, we investigated whether such a correlation could take place in the striatum. No changes in levels of rpS6 and eEF1A were observed in striatonigral and striatopallidal MSNs after acute (Fig. 10A-C) or chronic (Fig. 10E) $\mathrm{D}$-amph administration in the crude homogenate or in synap- 
A

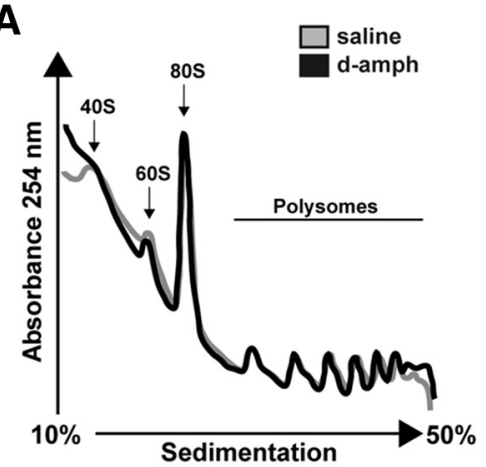

D
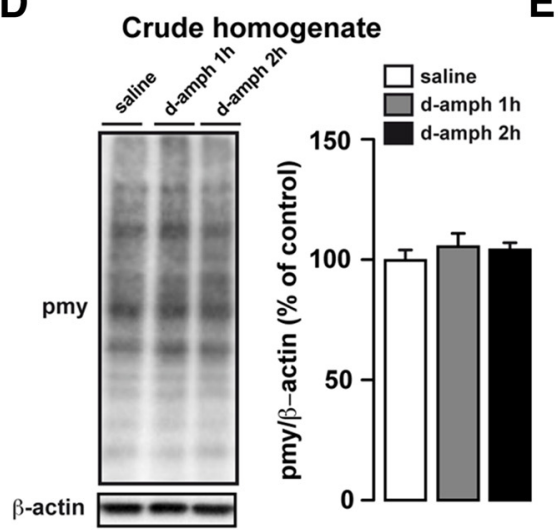

B

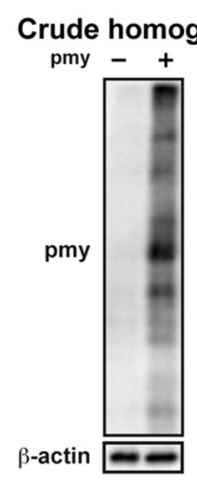

$\mathbf{E}$

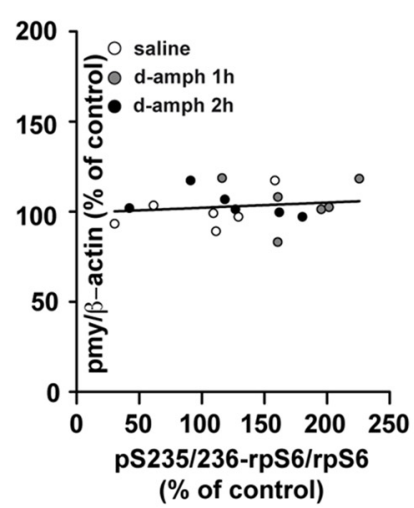

(\% of control)



Crude homogenate

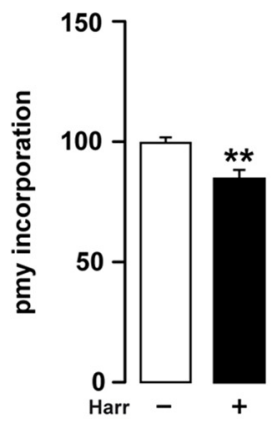

$\mathbf{F}$

\section{Synaptoneurosomes}
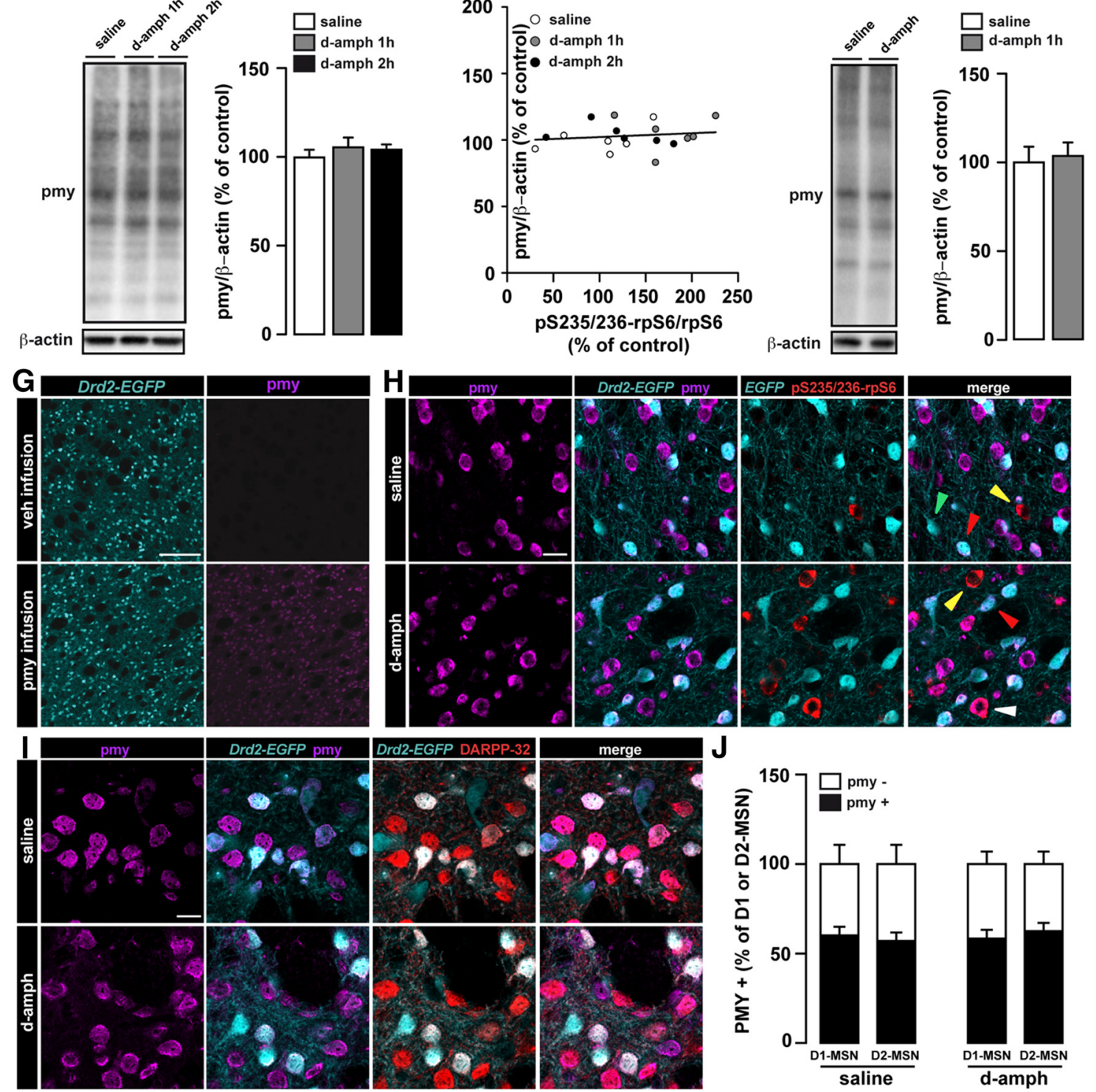

Figure 9. D-amph-induced $\mathrm{rpS6}$ phosphorylation is uncorrelated with global translation. $A$, Polysome profiles of whole striatal lysates from mice treated with saline and $\mathrm{D}$-amph $(10 \mathrm{mg} / \mathrm{kg})$ and killed at $1 \mathrm{~h}$ after injection ( $n=6$ mice/group). $\boldsymbol{B}$, Representative Western blot analyses of puromycin staining (pmy) of whole striatal lysates incubated 10 min with puromycin or not. $\boldsymbol{C}$, Representative and quantified Western blot analyses of puromycin staining (normalized to $\beta$-actin) of whole striatal lysates incubated 10 min with puromycin from mice killed $1 \mathrm{~h}$ after intrastriatal infusion of saline or harringtonin (harr, $10 \mu \mathrm{g} ; n=8$ mice/group). $\boldsymbol{D}$, Representative (left) and quantified (right) Western blot analyses of puromycin staining (pmy, normalized to $\beta$-actin) of whole striatal lysates incubated $10 \mathrm{~min}$ with puromycin from mice killed 1 or $2 \mathrm{~h}$ after saline or D-amph (10 $\mathrm{mg} / \mathrm{kg})$ treatment $(n=7 \mathrm{mice} / \mathrm{group})$. Results are represented as mean \pm SEM. $E$, Quantified Western blot signals were expressed as a correlation between the percentage of increase in pmy normalized to $\beta$-actin and the percentage of increase in pS235/236-rpS6 normalized to rpS6. $\boldsymbol{F}$, Representative (left) and quantified (right) Western blot analyses of striatal synaptoneurosomal preparations incubated $10 \mathrm{~min}$ with puromycin of mice killed $1 \mathrm{~h}$ after saline or D-amph (10 $\mathrm{mg} / \mathrm{kg}$ ) administration. Results are represented as mean \pm SEM $(n=8$ mice/group). G, Validation of anti-puromycin antibody specificity. Immunofluorescence for GFP (cyan) and pmy (magenta) of Drd2-EGFP mice perfused 5 min after vehicle (upper) or pmy infusion (27 $\mu$ g, i.c.v.) (bottom). Scale bar, $100 \mu \mathrm{m}$. $\boldsymbol{H}$, Triple immunostaining for GFP (cyan), pmy (magenta) (Figure legend continues.) 
Table 2. Effects of $\mathrm{D}$-amphetamine, haloperidol, and papaverine on elF4G, elF2a, and eEF2 phosphorylation in the striatum

\begin{tabular}{lccr}
\hline & pS1108-elF4G & pS51-elF2 $\alpha$ & pT56-eEF2 \\
\hline Saline $(n=6)$ & $100 \pm 12$ & $100 \pm 6$ & $100 \pm 8$ \\
D-amph $(n=6)$ & $129 \pm 13$ & $118 \pm 12$ & $98 \pm 2$ \\
Vehicle $(n=6)$ & $100 \pm 8$ & $100 \pm 5$ & $100 \pm 5$ \\
Haloperidol $(n=6)$ & $97 \pm 1$ & $99 \pm 6$ & $104 \pm 4$ \\
Saline $(n=6)$ & $100 \pm 18$ & $100 \pm 4$ & $100 \pm 5$ \\
Papaverine $(n=5)$ & $126 \pm 24$ & $108 \pm 3$ & $99 \pm 3$ \\
\hline
\end{tabular}

Drugs were administrated at the following doses and times before striatal extraction: $\mathrm{D}$-amphetamine, $10 \mathrm{mg} / \mathrm{kg}, 60$ $\mathrm{min}$; haloperidol, $0.5 \mathrm{mg} / \mathrm{kg}, 60 \mathrm{~min}$; and papaverine, $30 \mathrm{mg} / \mathrm{kg}, 15 \mathrm{~min}$. The level of each phosphoprotein was analyzed by Western blot and normalized to the respective total protein. Results are represented as mean \pm SEM and analyzed by Student's $t$ test.

toneurosomes (Fig. 10D), suggesting the lack of correlation between rpS6 phosphorylation and the accumulation of TOP mRNA-encoded proteins.

However, D-amph did not significantly increase the phosphorylation of S240/244 sites, which could contribute to enhance global mRNA translation and/or the synthesis of TOP mRNAencoded proteins. To test this hypothesis, the puromycin-based assay was first performed in mice treated with haloperidol, a drug that increases striatal pS240/244-rpS6 selectively in D2Rexpressing MSNs (Valjent et al., 2011; Bonito-Oliva et al., 2013). No changes in overall protein synthesis (Fig. 11A) or in levels of rpS6 and eEF1A (Fig. 11B) were observed after haloperidol treatment. Similar results were obtained with papaverine, which increases the phosphorylation of S235/236 (Fig. 6A) and S240/244 (saline $100 \pm 5.3$ and papaverine $145 \pm 16.1, p<0.05, n=6$ mice/group) sites in both D1R- and D2R-expressing MSNs (Fig. $11 C, D)$, indicating that the absence of regulation of protein synthesis observed with D-amph was not due to a lack of robust pS235/236-rpS6 or a lack of pS240/244-rpS6 phosphorylation. Together, our data provide strong evidence that striatal rpS6 phosphorylation is not correlated with changes in overall and TOP mRNA translation.

\section{Discussion}

Our study provides evidence for the cell-type-specific regulation of rpS6 phosphorylation in vivo through the cAMP/PKA/DARPP32/PP-1 pathway. Moreover, by combining pharmacological approaches with a novel in vivo technique, we demonstrate that rpS6 phosphorylation is not correlated with global protein synthesis or TOP mRNA translation in either striatonigral or striatopallidal neurons.

Our data show that rpS6 phosphorylation induced by D-amph occurs in a subpopulation of D1R-striatonigral MSNs. This activation requires the activation of dopamine D1R, but not of

\footnotetext{
(Figure legend continued.) and pS235/236-rpS6 (red) in coronal sections of the striatum from Drd2-EGFP mice that were pretreated with saline or D-amph 15 min before pmy infusion ( $27 \mu \mathrm{g}$, i.c.v., $n=4$ mice/treatment) and killed 5 min later. Note the presence of some GFP-expressing MSNs, which are also positive (red arrowhead) or negative (green arrowhead) for pmy and the

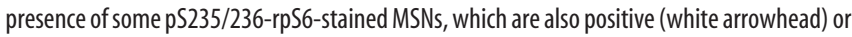
negative (yellow arrowhead) for pmy. Scale bar, $20 \mu \mathrm{m}$. I, Triple immunostaining for GFP (cyan), pmy (magenta), and DARPP-32 (red) in coronal sections of the striatum from Drd2-EGFP mice that were pretreated with saline or $\mathrm{D}$-amph 15 min before pmy infusion ( $27 \mu$ g, i.c.v., $n=$ 4 mice/treatment) and killed 5 min later. Note that pmy staining was observed in D2- and D1-MSNs, in ChAT-positive interneurons (yellow arrowhead), and most likely in other classes of interneurons (white arrowheads). Scale bar, $10 \mu \mathrm{m}$. J, Quantification of pmy-positive cells (pmy + , filled bars) in DARPP-32-positive/GFP-negative (D1-MSNs) and DARPP-32-positive/ GFP-positive (D2-MSNs) cells counted in coronal sections of Drd2-EGFP mice pretreated with saline or D-amph.
}

NMDA and mGluR1/5 glutamate receptors. Downstream the $\mathrm{D} 1 \mathrm{R}$ activation, the $\mathrm{cAMP} / \mathrm{PKA}$ signaling is critical in mediating this regulation because $\mathrm{D}$-amph-induced rpS6 phosphorylation was strongly reduced in $\mathrm{Gnal}^{+/-}$mice. In addition, our in vivo (papaverine) and ex vivo (forskolin) studies demonstrate that stimulation of cAMP/PKA signaling by itself is sufficient to induce striatal rpS6 phosphorylation. Despite this strong evidence, we cannot totally rule out that, in addition to cAMP production, D1Rs could signal through the concomitant activity of an additional pathway. Indeed, the inhibition of the cAMPmediated activation of PKA did not totally prevent rpS6 phosphorylation induced by $\mathrm{D}$-amph. This latter effect might result from D1R/Gq/PLC $\beta$ signaling, which contributes to the maintenance of PKA activity (Medvedev et al., 2013). However, it is important to keep in mind that the dopamine-stimulated cAMP production is decreased by only $\sim 30 \%$ in $\mathrm{Gnal}^{+/-}$mice (Corvol et al., 2007), an effect that could account for the remaining rpS6 phosphorylation.

As exemplified in the hippocampus, the regulation of $\mathrm{rpS} 6$ phosphorylation has been mostly attributed to activation of both mTORC1 and ERK signaling cascades (Ma and Blenis, 2009). In contrast, our study provides evidence for a role of modulation of phosphatase activity in vivo through PKA-induced DARPP-32 phosphorylation on T34 and concomitant inhibition of PP-1 (Hemmings et al., 1984). Indeed, DARPP-32 mutation at the PKA-dependent phosphorylation site T34 strongly attenuated the D-amph-induced increase in pS235/236-rpS6, indicating the involvement of PP-1 inhibition. These results are in agreement with the reported activity of PP-1 on all rpS6 C-terminal phosphorylation sites (Hutchinson et al., 2011). Interestingly, previous work showed that the administration of the antipsychotic haloperidol induces rpS6 phosphorylation at S235/S236 sites selectively in D2R-striatopallidal MSNs (Valjent et al., 2011; Bonito-Oliva et al., 2013). Similarly to D-amph, haloperidolinduced pS235/236-rpS6 requires the inhibition of PP-1, highlighting that PKA/DARPP-32/PP-1 signaling is critical for the regulation of striatal rpS6 phosphorylation. However, D-amphinduced rpS6 phosphorylation might be catalyzed partially by direct PKA action because previous studies identified PKA as an in vivo rpS6 kinase in pancreatic $\beta$-cells and cardiomyocytes (Moore et al., 2009; Yano et al., 2014).

Although rpS6 phosphorylation is commonly used as a marker of neuronal activity (Knight et al., 2012), its biological significance regarding the regulation of mRNA translation is still a matter of debate (Klann et al., 2004; Meyuhas, 2008; Mahoney et al., 2009; Sengupta et al., 2010; Xue and Barna, 2012). Previous studies suggested a causal relationship between rpS6 phosphorylation and increased global protein synthesis (Kruppa and Clemens, 1984; Roux et al., 2007). This is supported by early studies showing a higher percentage of phosphorylated rpS6 in polyribosomes than in subpolysomal fractions (Duncan and McConkey, 1982; Thomas et al., 1982). Moreover, rpS6 is localized at the interface between the two ribosomal subunits, where it interacts with mRNA, tRNA, and translation initiation factors (Nygård and Nilsson, 1990). However, the role of rpS6 in promoting mRNA translation has been contradicted because global protein synthesis is increased in phospho-deficient $\mathrm{rpS}^{\mathrm{P}-1-}$ mouse embryo fibroblasts (Ruvinsky et al., 2005). In the present study, we did not detect any change in overall protein synthesis accompanying increased rpS6 phosphorylation. After D-amph treatment, which strongly stimulated rpS6 phosphorylation, protein synthesis was not altered in the crude striatal fraction, in synaptoneurosomes, or in D1R-containing MSNs. Importantly, haloperidol 

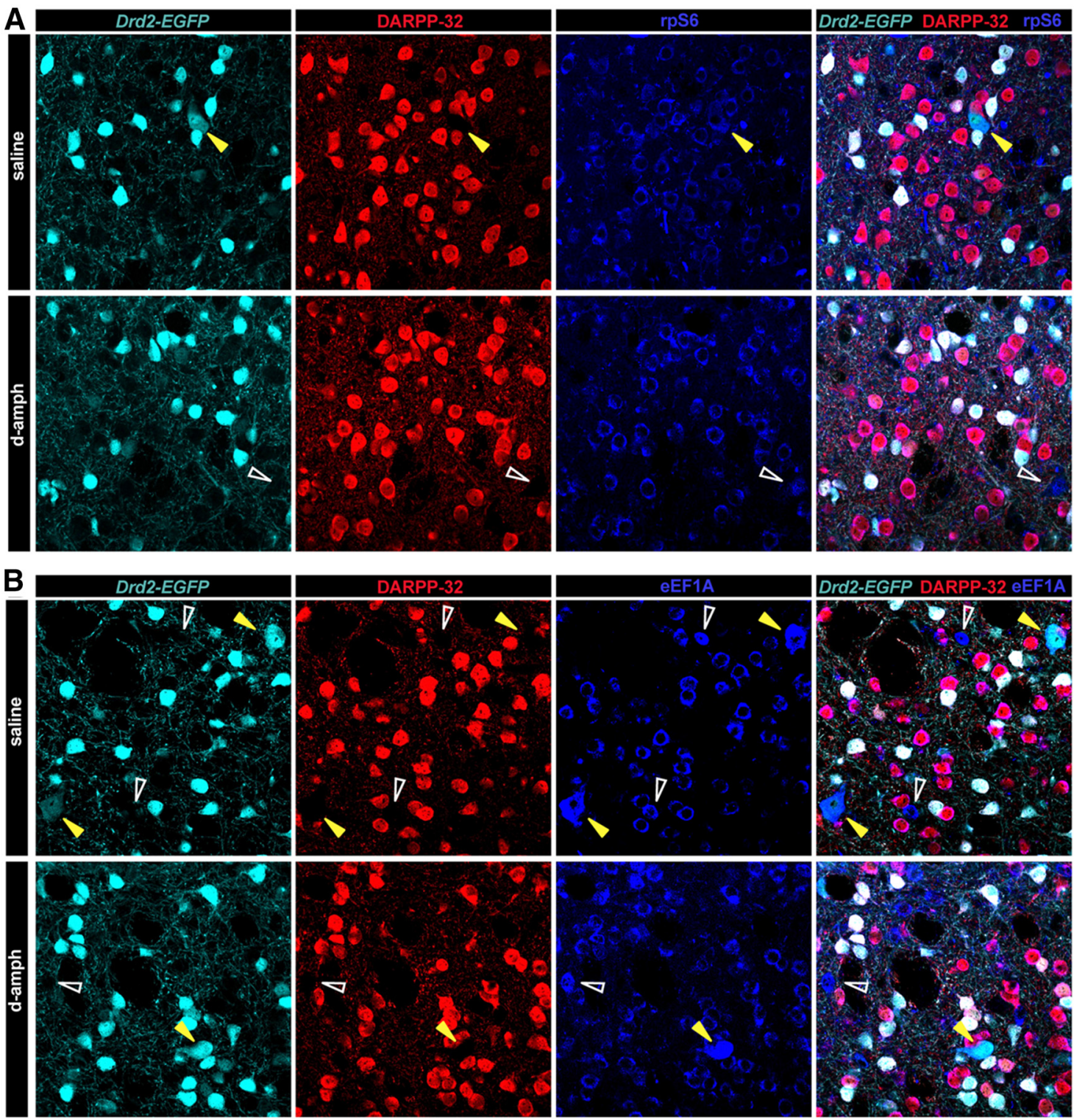

C

Crude homogenate

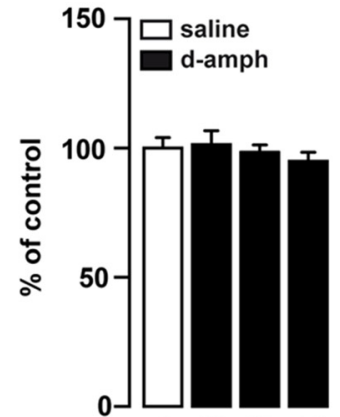

Time (min) $\quad 0 \quad 15 \quad 30 \quad 60$

eEF1a

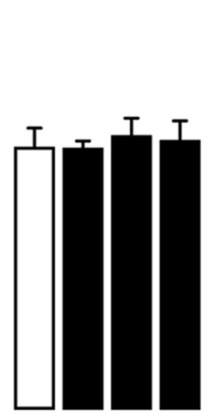

$\begin{array}{lllll}0 & 15 & 30 & 60 & \text { Time }(\min )\end{array}$ rpS6
D



Crude homogenate

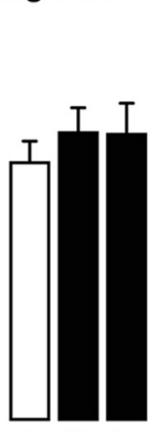

$0 \quad 15$
$\operatorname{rpS} 6$
E Synaptoneurosomes

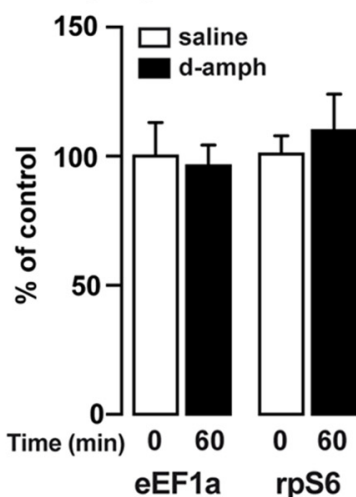

Figure 10. D-amph-induced rpS6 phosphorylation is not correlated with TOP mRNA translation. $\boldsymbol{A}, \boldsymbol{B}$, Triple immunostaining for GFP (cyan), DARPP-32 (red), and rpS6 (blue) ( $\boldsymbol{A})$ or eEF1A (blue) (B) in coronal sections of the striatum from Drd2-EGFP mice that were pretreated with saline or D-amph 15 min before perfusion. Yellow arrowheads indicate ChAT-positive interneurons and white arrowheads most likely correspond to GABAergic interneurons. Scale bar, $30 \mu \mathrm{m}$. C, D, Quantified Western blot analyses of eEF1A and rpS6 in crude homogenate 15,30 , or $60 \mathrm{~min}$ after acute saline or D-amph (10 mg/kg) administration $(\boldsymbol{C})$ or 15 and 30 after chronic saline or D-amph (10 mg/kg) administration (D) $(n=6 \mathrm{mice} / \mathrm{group})$. $\boldsymbol{E}$, Quantified Western blot analyses of eEF1A and rpS6 in synaptoneurosomes $60 \mathrm{~min}$ after saline or D-amph (10 mg/kg) administration ( $n=6 \mathrm{mice} / \mathrm{group})$. 
or papaverine treatment, both of which increase striatal rpS6 phosphorylation in at least four of the five phosphorylatable residues, failed to alter global protein synthesis. This suggests that the lack of correlation between these two events is observed in both D1R- and D2R-expressing MSNs whatever the nature of the pharmacological treatment.

Conversely, p70S6K1-mediated phosphorylation of $\mathrm{rpS} 6$ was widely believed to promote the translation of a specific subset of mRNAs bearing a 5'TOP tract. However, subsequent genetic studies did not support this long-standing model (Pende et al., 2004; Ruvinsky et al., 2005; Patursky-Polischuk et al., 2009). Even though the idea that rpS6 phosphorylation promotes TOP mRNA translation has been refuted in non-neuronal cells, increased phospho-rpS6 in the hippocampus has been correlated with enhanced translation of TOP mRNAs during long-term potentiation (Antion et al., 2008). In our study, translation of two well characterized TOP mRNAs, rpS6 and eEF1A, was unaltered after D-amph, haloperidol, or papaverine treatment, indicating that rpS6 phosphorylation is not correlated with the translation of this subset of mRNAs independently of the MSN subtype.

Altogether, our results indicate that the phosphorylation of rpS6 is not associated with global and/or TOP-encoded protein synthesis in MSNs. Future studies are required to determine whether in vivo striatal rpS6 phosphorylation regulates the translation of a specific subset of mRNAs. However, because all the drugs used in the present study induced rpS6 phosphorylation in a cAMP/PKA-dependent manner, we cannot rule out the possibility that the post-translational modification of rpS6 might have different outcomes depending on its upstream signal. An early study supported this hypothesis because the direct binding of mRNA to the $40 \mathrm{~S}$ ribosomal subunit has been shown to decrease or increase after cAMP-dependent or cAMP-independent phosphorylation of rpS6, respectively (Burkhard and Traugh, 1983). Therefore, we cannot exclude the possibility that, when another upstream signaling cascade is engaged, for example, mTORC1, rpS6 phosphorylation might have a different role than when it is mediated via cAMP/PKA signaling.

The absence of correlation between protein synthesis and rpS6 phosphorylation in our conditions suggests that rpS6 might be involved in extra-ribosomal functions. For example, in the mouse liver, rpS6 phosphorylation has been shown to play a critical role in the control of the ribosome biogenesis transcriptional program (Chauvin et al., 2014). Alternatively, rpS6 phosphorylation could regulate the dissociation of $\mathrm{rpS} 6$ from the $40 \mathrm{~S}$ ribosomal subunit. Such a mechanism has been reported previously for the ribosomal protein rpL13a, which, when phosphorylated, is released from the $t$ test.
B
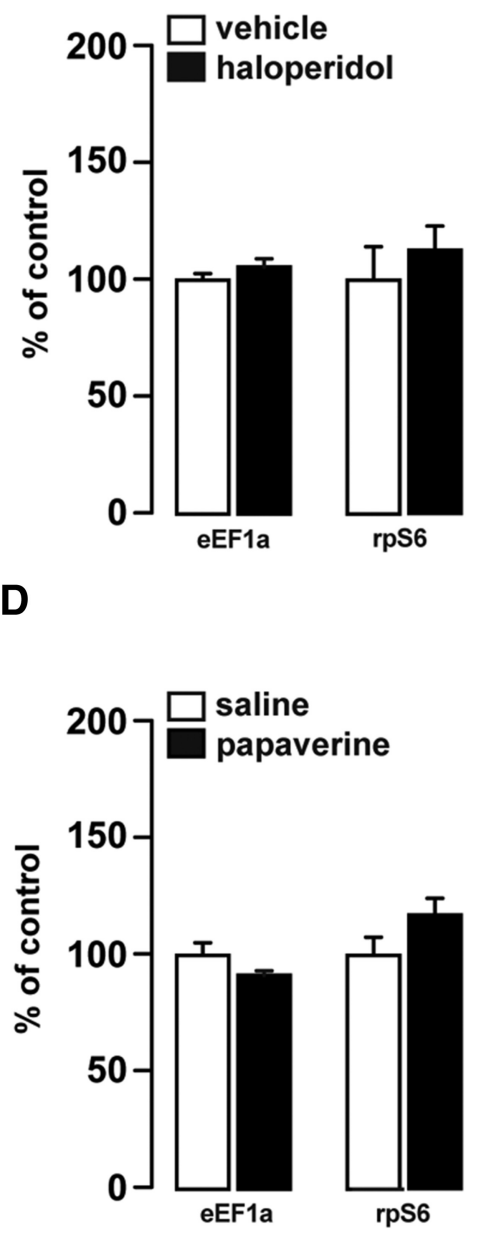

D

Figure 11. Haloperidol-and papaverine-induced rpS6 phosphorylation is not correlated with global and TOP mRNA translation. striatal lysates incubated 10 min with puromycin from mice killed $1 \mathrm{~h}$ after vehicle or haloperidol $(0.5 \mathrm{mg} / \mathrm{kg})$ treatment $(n=6$ mice/group). B, Quantified Western blot analyses of eEF1A and rpS6 $1 \mathrm{~h}$ after vehicle or haloperidol $(0.5 \mathrm{mg} / \mathrm{kg})$ administration ( $\mathrm{mg} / \mathrm{kg}$ ) treatment ( $n=5-6$ mice/group). D, Quantified Western blot analyses of eEF1A and rpS6, 15 min after saline or papaverine ( $30 \mathrm{mg} / \mathrm{kg}$ ) administration ( $n=5-6$ mice/group). Results are represented as mean $\pm S E M$ and were analyzed by Student's

$60 \mathrm{~S}$ ribosomal subunit and acts as a silencer of targeted mRNAs (Mazumder et al., 2003). Finally, the ribosomal protein rpS6 has been shown recently to have extra-translational functions via its interaction with histone deacetylases and mTOR complex 2 (Oh et al., 2010; Kappeler et al., 2012). However, whether these translationunrelated responses occur in the brain remains to be addressed.

In conclusion, our results provide novel mechanistic insight into the cell-type-specific regulation of rpS6 phosphorylation. The involvement of the cAMP/PKA/DARPP-32/PP-1 signaling highlights the critical role of this pathway in the posttranslational modification of rpS6 in striatal MSNs. Finally, the lack of a relationship between in vivo PKA-dependent rpS6 phosphorylation and changes in global or TOP mRNA translation raised the intriguing hypothesis that, depending on the upstream signal engaged and cell-type population where it occurred, this posttranslational modification could trigger multiple cellular responses (perhaps distinct from protein synthesis). 


\section{References}

Anderson SM, Famous KR, Sadri-Vakili G, Kumaresan V, Schmidt HD, Bass CE, Terwilliger EF, Cha JH, Pierce RC (2008) CaMKII: a biochemical bridge linking accumbens dopamine and glutamate systems in cocaine seeking. Nat Neurosci 11:344-353. CrossRef Medline

Antion MD, Hou L, Wong H, Hoeffer CA, Klann E (2008) mGluRdependent long-term depression is associated with increased phosphorylation of 66 and synthesis of elongation factor 1A but remains expressed in S6K-deficient mice. Mol Cell Biol 28:2996-3007. CrossRef Medline

Bandi HR, Ferrari S, Krieg J, Meyer HE, Thomas G (1993) Identification of $40 \mathrm{~S}$ ribosomal protein S6 phosphorylation sites in Swiss mouse 3T3 fibroblasts stimulated with serum. J Biol Chem 268:4530-4533. Medline

Bateup HS, Svenningsson P, Kuroiwa M, Gong S, Nishi A, Heintz N, Greengard P (2008) Cell type-specific regulation of DARPP-32 phosphorylation by psychostimulant and antipsychotic drugs. Nat Neurosci 11:932-939. CrossRef Medline

Belandia B, Brautigan D, Martín-Pérez J (1994) Attenuation of ribosomal protein S6 phosphatase activity in chicken embryo fibroblasts transformed by Rous sarcoma virus. Mol Cell Biol 14:200-206. Medline

Belluscio L, Gold GH, Nemes A, Axel R (1998) Mice deficient in G(olf) are anosmic. Neuron 20:69-81. CrossRef Medline

Bertran-Gonzalez J, Bosch C, Maroteaux M, Matamales M, Hervé D, Valjent E, Girault JA (2008) Opposing patterns of signaling activation in dopamine D1 and D2 receptor-expressing striatal neurons in response to cocaine and haloperidol. J Neurosci 28:5671-5685. CrossRef Medline

Bertran-Gonzalez J, Hervé D, Girault JA, Valjent E (2010) What is the degree of segregation between striatonigral and striatopallidal projections? Front Neuroanat 4:pii:136. CrossRef Medline

Bonito-Oliva A, Pallottino S, Bertran-Gonzalez J, Girault JA, Valjent E, Fisone G (2013) Haloperidol promotes mTORC1-dependent phosphorylation of ribosomal protein S6 via dopamine- and cAMP-regulated phosphoprotein of $32 \mathrm{kDa}$ and inhibition of protein phosphatase- 1 . Neuropharmacology 72:197-203. CrossRef Medline

Burkhard SJ, Traugh JA (1983) Changes in ribosome function by cAMPdependent and cAMP-independent phosphorylation of ribosomal protein S6. J Biol Chem 258:14003-14008. Medline

Cadoni C, Pinna A, Russi G, Consolo S, Di Chiara G (1995) Role of vesicular dopamine in the in vivo stimulation of striatal dopamine transmission by amphetamine: evidence from microdialysis and Fos immunohistochemistry. Neuroscience 65:1027-1039. CrossRef Medline

Cass LA, Summers SA, Prendergast GV, Backer JM, Birnbaum MJ, Meinkoth JL (1999) Protein kinase A-dependent and -independent signaling pathways contribute to cyclic AMP-stimulated proliferation. Mol Cell Biol 19:5882-5891. Medline

Chauvin C, Koka V, Nouschi A, Mieulet V, Hoareau-Aveilla C, Dreazen A, Cagnard N, Carpentier W, Kiss T, Meyuhas O, Pende M (2014) Ribosomal protein $\mathrm{S} 6$ kinase activity controls the ribosome biogenesis transcriptional program. Oncogene 33:474-483. CrossRef Medline

Corvol JC, Valjent E, Pascoli V, Robin A, Stipanovich A, Luedtke RR, Belluscio L, Girault JA, Hervé D (2007) Quantitative changes in Galphaolf protein levels, but not D1 receptor, alter specifically acute responses to psychostimulants. Neuropsychopharmacology 32:1109-1121. CrossRef Medline

Costa-Mattioli M, Sossin WS, Klann E, Sonenberg N (2009) Translational control of long-lasting synaptic plasticity and memory. Neuron 61:10-26. CrossRef Medline

Crittenden JR, Graybiel AM (2011) Basal Ganglia disorders associated with imbalances in the striatal striosome and matrix compartments. Front Neuroanat 5:59. Medline

David A, Dolan BP, Hickman HD, Knowlton JJ, Clavarino G, Pierre P, Bennink JR, Yewdell JW (2012) Nuclear translation visualized by ribosomebound nascent chain puromycylation. J Cell Biol 197:45-57. CrossRef Medline

Dufner A, Thomas G (1999) Ribosomal S6 kinase signaling and the control of translation. Exp Cell Res 253:100-109. CrossRef Medline

Duncan R, McConkey EH (1982) Rapid alterations in initiation rate and recruitment of inactive RNA are temporally correlated with S6 phosphorylation. Eur J Biochem 123:539-544. Medline

Felder CC, Jose PA, Axelrod J (1989) The dopamine-1 agonist, SKF 82526, stimulates phospholipase-C activity independent of adenylate cyclase. J Pharmacol Exp Ther 248:171-175. Medline
Franklin K, Paxinos G (2008) The mouse brain in stereotaxic coordinates, Ed 3. New York: Academic.

Fujiyama F, Unzai T, Nakamura K, Nomura S, Kaneko T (2006) Difference in organization of corticostriatal and the thalamostriatal synapses between patch and matrix compartments of rat neostriatum. Eur J Neurosci 24: 2813-2824. Medline

Gong S, Zheng C, Doughty ML, Losos K, Didkovsky N, Schambra UB, Nowak NJ, Joyner A, Leblanc G, Hatten ME, Heintz N (2003) A gene expression atlas of the central nervous system based on bacterial artificial chromosomes. Nature 425:917-925. CrossRef Medline

Graber TE, Hébert-Seropian S, Khoutorsky A, David A, Yewdell JW, Lacaille JC, Sossin WS (2013) Reactivation of stalled polyribosomes in synaptic plasticity. Proc Natl Acad Sci U S A 110:16205-16210. CrossRef Medline

Greengard P (2001) The neurobiology of slow synaptic transmission. Science 294:1024-1030. CrossRef Medline

Hemmings HC Jr, Nairn AC, Aswad DW, Greengard P (1984) DARPP-32, a dopamine- and adenosine $3^{\prime}: 5^{\prime}$-monophosphate-regulated phosphoprotein enriched in dopamine-innervated brain regions. II. Purification and characterization of the phosphoprotein from bovine caudate nucleus. J Neurosci 4:99-110. Medline

Hervé D, Lévi-Strauss M, Marey-Semper I, Verney C, Tassin JP, Glowinski J, Girault JA (1993) G(olf) and Gs in rat basal ganglia: possible involvement of G(olf) in the coupling of dopamine D1 receptor with adenylyl cyclase. J Neurosci 13:2237-2248. Medline

House C, Wettenhall RE, Kemp BE (1987) The influence of basic residues on the substrate specificity of protein kinase C. J Biol Chem 262:772-777. Medline

Hutchinson JA, Shanware NP, Chang H, Tibbetts RS (2011) Regulation of ribosomal protein $\mathrm{S} 6$ phosphorylation by casein kinase 1 and protein phosphatase 1. J Biol Chem 286:8688-8696. CrossRef Medline

Kappeler KV, Zhang J, Dinh TN, Strom JG, Chen QM (2012) Histone deacetylase 6 associates with ribosomes and regulates de novo protein translation during arsenite stress. Toxicol Sci 127:246-255. CrossRef Medline

Klann E, Antion MD, Banko JL, Hou L (2004) Synaptic plasticity and translation initiation. Learn Mem 11:365-372. CrossRef Medline

Knight ZA, Tan K, Birsoy K, Schmidt S, Garrison JL, Wysocki RW, Emiliano A, Ekstrand MI, Friedman JM (2012) Molecular profiling of activated neurons by phosphorylated ribosome capture. Cell 151:1126-1137. CrossRef Medline

Krieg J, Hofsteenge J, Thomas G (1988) Identification of the 40 S ribosomal protein $\mathrm{S} 6$ phosphorylation sites induced by cycloheximide. J Biol Chem 263:11473-11477. Medline

Kruppa J, Clemens MJ (1984) Differential kinetics of changes in the state of phosphorylation of ribosomal protein $\mathrm{S} 6$ and in the rate of protein synthesis in MPC 11 cells during tonicity shifts. EMBO J 3:95-100. Medline

Lobo MK, Zaman S, Damez-Werno DM, Koo JW, Bagot RC, DiNieri JA, Nugent A, Finkel E, Chaudhury D, Chandra R, Riberio E, Rabkin J, Mouzon E, Cachope R, Cheer JF, Han MH, Dietz DM, Self DW, Hurd YL, Vialou V, et al. (2013) DeltaFosB induction in striatal medium spiny neuron subtypes in response to chronic pharmacological, emotional, and optogenetic stimuli. J Neurosci 33:18381-18395. CrossRef Medline

Lobo MK, Nestler EJ (2011) The striatal balancing act in drug addiction: distinct roles of direct and indirect pathway medium spiny neurons. Front Neuroanat 5:41. CrossRef Medline

Ma XM, Blenis J (2009) Molecular mechanisms of mTOR-mediated translational control. Nat Rev Mol Cell Biol 10:307-318. CrossRef Medline

Mahoney SJ, Dempsey JM, Blenis J (2009) Cell signaling in protein synthesis ribosome biogenesis and translation initiation and elongation. Prog Mol Biol Transl Sci 90:53-107. CrossRef Medline

Mazumder B, Sampath P, Seshadri V, Maitra RK, DiCorleto PE, Fox PL (2003) Regulated release of L13a from the 60S ribosomal subunit as a mechanism of transcript-specific translational control. Cell 115:187-198. CrossRef Medline

Medvedev IO, Ramsey AJ, Masoud ST, Bermejo MK, Urs N, Sotnikova TD, Beaulieu JM, Gainetdinov RR, Salahpour A (2013) D1 dopamine receptor coupling to PLCbeta regulates forward locomotion in mice. J Neurosci 33:18125-18133. CrossRef Medline

Meyuhas O (2008) Physiological roles of ribosomal protein S6: one of its kind. Int Rev Cell Mol Biol 268:1-37. CrossRef Medline

Miller JS, Barr JL, Harper LJ, Poole RL, Gould TJ, Unterwald EM (2014) The 
GSK3 signaling pathway is activated by cocaine and is critical for cocaine conditioned reward in mice. PLoS One 9:e88026. CrossRef Medline

Moore CE, Xie J, Gomez E, Herbert TP (2009) Identification of cAMPdependent kinase as a third in vivo ribosomal protein S6 kinase in pancreatic beta-cells. J Mol Biol 389:480-494. CrossRef Medline

Nishi A, Watanabe Y, Higashi H, Tanaka M, Nairn AC, Greengard P (2005) Glutamate regulation of DARPP-32 phosphorylation in neostriatal neurons involves activation of multiple signaling cascades. Proc Natl Acad Sci U S A 102:1199-1204. CrossRef Medline

Nishi A, Kuroiwa M, Miller DB, O'Callaghan JP, Bateup HS, Shuto T, Sotogaku N, Fukuda T, Heintz N, Greengard P, Snyder GL (2008) Distinct roles of PDE4 and PDE10A in the regulation of cAMP/PKA signaling in the striatum. J Neurosci 28:10460-10471. CrossRef Medline

Nishi A, Kuroiwa M, Shuto T (2011) Mechanisms for the modulation of dopamine $\mathrm{d}(1)$ receptor signaling in striatal neurons. Front Neuroanat 5:43. Medline

Nygård O, Nilsson L (1990) Translational dynamics. Interactions between the translational factors, tRNA and ribosomes during eukaryotic protein synthesis. Eur J Biochem 191:1-17. CrossRef Medline

Oh WJ, Wu CC, Kim SJ, Facchinetti V, Julien LA, Finlan M, Roux PP, Su B, Jacinto E (2010) mTORC2 can associate with ribosomes to promote cotranslational phosphorylation and stability of nascent Akt polypeptide. EMBO J 29:3939-3951. CrossRef Medline

Ouimet CC, Miller PE, Hemmings HC Jr, Walaas SI, Greengard P (1984) DARPP-32, dopamine- and adenosine 3':5'-monophosphate-regulated phosphoprotein enriched in dopamine-innervated brain regions. III. Immunocytochemical localization. J Neurosci 4:111-124. Medline

Patursky-Polischuk I, Stolovich-Rain M, Hausner-Hanochi M, Kasir J, Cybulski N, Avruch J, Rüegg MA, Hall MN, Meyuhas O (2009) The TSCmTOR pathway mediates translational activation of TOP mRNAs by insulin largely in a raptor- or rictor-independent manner. Mol Cell Biol 29:640-649. CrossRef Medline

Pende M, Um SH, Mieulet V, Sticker M, Goss VL, Mestan J, Mueller M, Fumagalli S, Kozma SC, Thomas G (2004) S6K1(-/-)/S6K2(-/-) mice exhibit perinatal lethality and rapamycin-sensitive $5^{\prime}$-terminal oligopyrimidine mRNA translation and reveal a mitogen-activated protein kinase-dependent S6 kinase pathway. Mol Cell Biol 24:3112-3124. CrossRef Medline

Roux PP, Shahbazian D, Vu H, Holz MK, Cohen MS, Taunton J, Sonenberg $\mathrm{N}$, Blenis J (2007) RAS/ERK signaling promotes site-specific ribosomal protein S6 phosphorylation via RSK and stimulates cap-dependent translation. J Biol Chem 282:14056-14064. CrossRef Medline

Ruvinsky I, Sharon N, Lerer T, Cohen H, Stolovich-Rain M, Nir T, Dor Y, Zisman P, Meyuhas O (2005) Ribosomal protein S6 phosphorylation is a determinant of cell size and glucose homeostasis. Genes Dev 19:21992211. CrossRef Medline

Sengupta S, Peterson TR, Sabatini DM (2010) Regulation of the mTOR complex 1 pathway by nutrients, growth factors, and stress. Mol Cell 40:310-322. CrossRef Medline

Snyder GL, Girault JA, Chen JY, Czernik AJ, Kebabian JW, Nathanson JA, Greengard P (1992) Phosphorylation of DARPP-32 and protein phosphatase inhibitor-1 in rat choroid plexus: regulation by factors other than dopamine. J Neurosci 12:3071-3083. Medline
Sonenberg N, Hinnebusch AG (2009) Regulation of translation initiation in eukaryotes: mechanisms and biological targets. Cell 136:731-745. CrossRef Medline

Stolovich M, Tang H, Hornstein E, Levy G, Cohen R, Bae SS, Birnbaum MJ, Meyuhas O (2002) Transduction of growth or mitogenic signals into translational activation of TOP mRNAs is fully reliant on the phosphatidylinositol 3-kinase-mediated pathway but requires neither S6K1 nor rpS6 phosphorylation. Mol Cell Biol 22:8101-8113. CrossRef Medline

Sturgill TW, Ray LB, Erikson E, Maller JL (1988) Insulin-stimulated MAP-2 kinase phosphorylates and activates ribosomal protein S6 kinase II. Nature 334:715-718. CrossRef Medline

Svenningsson P, Tzavara ET, Carruthers R, Rachleff I, Wattler S, Nehls M, McKinzie DL, Fienberg AA, Nomikos GG, Greengard P (2003) Diverse psychotomimetics act through a common signaling pathway. Science 302 : 1412-1415. CrossRef Medline

Tang H, Hornstein E, Stolovich M, Levy G, Livingstone M, Templeton D, Avruch J, Meyuhas O (2001) Amino acid-induced translation of TOP mRNAs is fully dependent on phosphatidylinositol 3-kinase-mediated signaling, is partially inhibited by rapamycin, and is independent of S6K1 and rpS6 phosphorylation. Mol Cell Biol 21:8671-8683. CrossRef Medline

Thomas G, Martin-Pérez J, Siegmann M, Otto AM (1982) The effect of serum, EGF, PGF2 alpha and insulin on S6 phosphorylation and the initiation of protein and DNA synthesis. Cell 30:235-242. CrossRef Medline

Tsokas P, Grace EA, Chan P, Ma T, Sealfon SC, Iyengar R, Landau EM, Blitzer RD (2005) Local protein synthesis mediates a rapid increase in dendritic elongation factor $1 \mathrm{~A}$ after induction of late long-term potentiation. J Neurosci 25:5833-5843. CrossRef Medline

Valjent E, Pascoli V, Svenningsson P, Paul S, Enslen H, Corvol JC, Stipanovich A, Caboche J, Lombroso PJ, Nairn AC, Greengard P, Hervé D, Girault JA (2005) Regulation of a protein phosphatase cascade allows convergent dopamine and glutamate signals to activate ERK in the striatum. Proc Natl Acad Sci U S A 102:491-496. CrossRef Medline

Valjent E, Bertran-Gonzalez J, Hervé D, Fisone G, Girault JA (2009) Looking BAC at striatal signaling: cell-specific analysis in new transgenic mice. Trends Neurosci 32:538-547. CrossRef Medline

Valjent E, Bertran-Gonzalez J, Bowling H, Lopez S, Santini E, Matamales M, Bonito-Oliva A, Hervé D, Hoeffer C, Klann E, Girault JA, Fisone G (2011) Haloperidol regulates the state of phosphorylation of ribosomal protein S6 via activation of PKA and phosphorylation of DARPP-32. Neuropsychopharmacology 36:2561-2570. CrossRef Medline

Wickens JR, Reynolds JN, Hyland BI (2003) Neural mechanisms of rewardrelated motor learning. Curr Opin Neurobiol 13:685-690. CrossRef Medline

Xue S, Barna M (2012) Specialized ribosomes: a new frontier in gene regulation and organismal biology. Nat Rev Mol Cell Biol 13:355-369. CrossRef Medline

Yano T, Ferlito M, Aponte A, Kuno A, Miura T, Murphy E, Steenbergen C (2014) The pivotal role of mTORC2 and involvement of ribosomal protein S6 in cardioprotective signaling. Circ Res 114:1268-1280. CrossRef Medline 